\title{
A review of sustainable solar irrigation systems for Sub- Saharan Africa
}

\author{
Saeed Mohammed Wazed ${ }^{\mathrm{a}}$, Ben Richard Hughes ${ }^{\mathrm{a}}$, Dominic O’Connor ${ }^{\mathrm{a}}$, John Kaiser Calautit ${ }^{\mathrm{b}}$ \\ ${ }^{a}$ Energy2050, Mechanical Engineering, Faculty of Engineering, University of Sheffield, Sheffield, South \\ Yorkshire S10 2TN, United Kingdom \\ ${ }^{\mathrm{b}}$ Department of Architecture and Built Environment, University of Nottingham, Nottingham NG7 2RD, United \\ Kingdom
}

\begin{abstract}
This investigation focused on the research undertaken on solar photovoltaic (PV) and solar thermal technologies for pumping water generally for irrigation of remote rural farms specifically considering the Sub-Saharan African region. Solar PV systems have been researched extensively for irrigation purposes due to the rise in Oil prices and the upscaling in commercialisation of PV technology. Based on the literature the most effective PV system is presented for the irrigation of a small scare remote rural farm with respect to the cost, pumping capacity and system efficiency. Similarly, solar thermal systems are reviewed and the most effective system described. Unlike PV technology, solar thermal technology for water pumping is lacking especially in small scale operations. However, with the possibility of local production, low investment cost, easy maintenance and lower carbon footprint, solar thermal water pumping technologies may be able to overcome the shortcomings of the PV technology that has stopped widespread use of the technology for irrigation applications. Taking into consideration recent developments in concentrated solar technologies using the Stirling engine, novel solar thermal water pumping systems may be developed. This review also highlighted the different methodologies such as modelling, used to investigate and optimise the performance of solar powered systems.
\end{abstract}

Keywords Solar energy; Solar water pumping; Photovoltaics; Concentrated solar thermal; Stirling engine; Irrigation

\section{Introduction}

Population growth and food insecurity necessitates an increase in farming and irrigation all over the world. The focus here is not only to produce more but to do so in a manner that protects the environment. Moreover, the impact on poorer nations, which are already struggling with food shortage, is far more adverse than others as more land and energy is required to meet the requirements of the future. This creates a need for the development of sustainable technologies that can be implemented to utilise the readily available local resources to drive the cost of the irrigation systems down. 
The Sub-Saharan region in Africa is one such region that is marred by inconsistent supply of safe water supplies. Contaminated ground water and long dry spells means that the main source of water in these regions are the rich groundwater reserves. Only $10 \%$ of this region utilises groundwater and most of this stems from the lack of economic incentives [1]. The cost of harvesting the reserves are very high. Not only is the initial investment high for purchasing generators and pumps but also the ongoing inflation in fuel costs leads to a consistent increase in operational and maintenance costs [2]. Such costs are extremely high for remote small scale independent farmers to bear.

The focus of this review is to investigate affordable irrigation systems that will be portable and utilise the local resources for manufacture and maintenance. Emphasis is also provided on the use of renewable energy resources to negate the requirement of fossil fuel driven motors (generally diesel powered) and pumps to further reduce the running cost of irrigation. Severe draught, lack of rain and long dry spells provides the opportunity for the utilisation of solar power in Sub-Saharan Africa, with both solar thermal and Photovoltaic (PV) technologies [3], and hence, is considered the focus of this review.

In the review, solar thermal and PV technologies will be compared on the basis of cost, power output and flow generated. The above parameters have been selected in order to design a system that will be viable for the independent farmer for irrigation of remote small scale farms in the Sub-Sharan African region with average small scale farm size of 1 ha according to the Food and Agriculture Organisation (FAO) [4].

The research on solar thermal power has not been as prominent as PV panels in recent times for water pumping applications. However, major development in solar thermal technologies incorporating Stirling Engines warrants a review of solar thermal systems for irrigation because of it's potential to work at low temperatures and relatively simple construction. This review paper highlights major technological developments made in PV irrigation systems, solar thermal irrigation systems and new developments in solar thermal technology that could be utilised in irrigation, with focus on medium to low powered Stirling cycle engines. The findings are summarised and the performance of the systems are compared to identify the key advantages and disadvantages of each technology.

\section{Research methodology}

A literature review is performed on PV and solar thermal irrigation systems. While there is numerous research on PV and Solar thermal technologies, the focus on this review is to study the implementation of the technology in irrigation. To obtain the research material for this literature review, keyword search has been utilised incorporating, "solar water pumps", "solar irrigation", "PV irrigation", "solar thermal irrigation", "PV water pumping systems", "Stirling pumps", "Rankine Cycle water pumps", "ORC water pumps", "ORC irrigation" and "Stirling Irrigation". No location bias has been set. The University of Sheffield's "StarPlus Library Discovery" search tool, "Science-Direct" search engine and the "Google" search engine has been utilised.

PV system reviews have been divided in 4 sections:

- PV irrigation technology reviews - Contains reviews of papers which enlists the various PV technologies that have been studied in the years prior to the publication.

- PV irrigations systems - Contains reviews of papers which describe unique irrigation systems design.

- PV irrigation systems performance - Contains reviews of papers that discuss technologies and control systems that can be used to optimise PV irrigation systems

- PV irrigation technology in comparison to other technologies - Contains reviews of papers that compare PV irrigation technologies against other technologies including Diesel generated pump systems and Renewable energy generated pump systems.

Solar Thermal system reviews have been divided in 3 sections: 
- Solar thermal irrigation technology reviews - Contains reviews of papers which enlists the various solar thermal technologies that have been studied in the years prior to the publication.

- Conventional solar thermal technologies - Contains reviews of papers discussing solar thermal technologies based on the Rankine cycle.

- Unconventional solar thermal technologies - Contains reviews of papers discussing solar thermal technologies based on Stirling cycle and other two stroke systems.

After the literature review was performed each solar powered technology (PV and Solar Thermal) is then individually analysed. A summary table of all the technology systems reviewed is presented and the best irrigation set-up has been established. Following this the future of solar irrigation technology is discussed.

\section{PV irrigation systems}

PV Technologies convert solar energy into electrical energy and then coupled with an electric motor is used to drive an electric pump. Fig. 1 depicts a typical PV irrigation set up. This system can be further enhanced depending on the output requirement, charge regulation based on the requirement of the pump (AC/DC) as well as the incorporation of a battery to counter the fluctuation of solar irradiation available throughout the day or even for irrigation at night, when lower water losses and higher irrigation uniformity is observed [5].

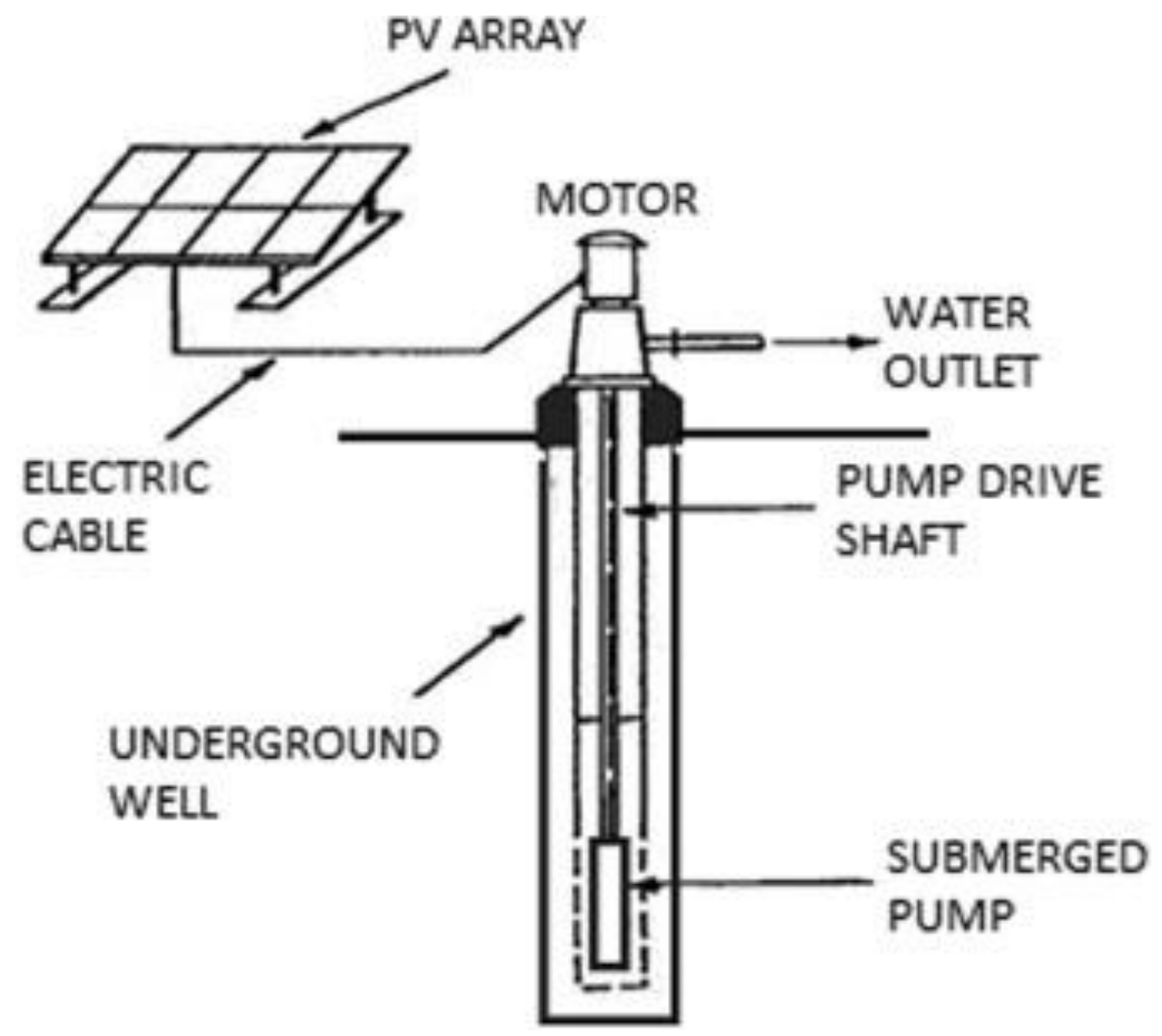

Fig. 1. Schematic of a simple PV irrigation set up for groundwater retrieval [6].

The water outlet from the irrigation system (depicted in Fig. 1) can be used either directly for irrigation or can be used to fill up a water storage tank. An advantage of the water storage tank is that it can be a substitute of the battery system, wherein the potential energy of the stored water can be utilised for drip irrigation. 
Photooltaic systems are generally very simple to implement, and an adequately designed system is efficient and can compete with other systems when operational and maintenance costs are considered. However, the initial investment is often identified as a major turn off [7]. While PV systems are easier to maintain than most other renewable energy systems, there are lots of factors that limit its use including, inconsistent solar irradiation, expensive tracking systems, reduction in efficiency due to overheating of panel systems, lower output due to energy conversion and one of the major issues identified in recent times is the large environmental impact in the production of PV panels [7-9].

A decrease in the cost of PV technology has meant many rural developments have been keen on utilising the technology because of this, a great amount of research has been conducted on solar PV technologies for water pumping in the recent years so much so that photovoltaic irrigation systems have become synonymous with solar-powered irrigation. Significant research has been conducted on performance, feasibility and economic viability of various PV systems as detailed below.

\subsection{PV irrigation technology reviews}

Chandel et al. [10] reviewed technologies for irrigation and supply of drinking water to communities that utilises solar PV technology. The study focussed on new technology updates, efficiency, analysis of the performance, efficient sizing of panels, degradation of supplying power to the pump from the PV panels and the economic and environmental aspects of utilising PV technology. In comparison to diesel / conventional electric system, PV systems were identified to be more economically viable in urban and remote rural areas with a payback time of 4-6 years achieved. For shallow wells (10-20 m deep), AC motor pump systems showed similar water output levels when compared to DC motor pump systems, however, at higher depths $(30-50 \mathrm{~m}) \mathrm{DC}$ motor systems provide higher flowrates. The efficiency of different types of solar cells are as per indicated in Table 1 (as tabularised by Green et al. [11]) with Multijunction five-junction cells demonstrating the highest efficiency of almost 39\%. Thin film CdTe cells, which are widely available commercially, are rated at an efficiency of $21 \%$.

Table 1. PV cell efficiency at $25^{\circ} \mathrm{C}$ and $1000 \mathrm{~W} / \mathrm{m}^{2}[11]$.

$\begin{array}{llll}\text { PV cell materials type } & \text { Efficiency }(\%) & \text { PV cell materials type } & \text { Efficiency } \\ \text { Silicon } & & \text { Dye mini module } & 10.7 \pm 0.4 \\ \text { Si (crystalline) } & 26.3 \pm 0.5 & \text { Thin-film chalcogenide } & \\ \text { Si (multi-crystalline) } & 21.3 \pm 0.6 & \text { CIGS (cell) } & 21.0 \pm 0.6 \\ \text { Si (thin-film minimodule) } & 10.5 \pm 0.3 & \text { CIGS (minimodule) } & 18.7 \pm 0.6 \\ \text { III-V cells } & & \text { CdTe(cell) } & 21.0 \pm 0.4 \\ \text { GaAs (thin film) } & 28.8 \pm 0.9 & \text { Multi-junction devices } & \\ \text { GaAs (multi crystalline) } & 18.4 \pm 0.5 & \text { Five-Junction Cell (bonded) } & 38.8 \pm 1.2 \\ \text { InP (crystalline) } & 22.1 \pm 0.7 & \text { InGaP/GaAs/InGaAs } & 37.9 \pm 1.2 \\ \text { Dye sensitised } & & \text { a-Si/nc-Si/nc-Si (thin film) } & 14.0 \pm 0.4 \\ \text { Dye } & 11.9 \pm 0.4 & \text { Si (amorphous) } & 10.2 \pm 0.3\end{array}$

The efficiency of the system can be further improved using positive displacement pumps, diaphragm pumps and progressing cavity pumps were capable of pumping efficiencies of up to $70 \%$. A Maximum Power Point Tracking [12] system could be utilised for further increasing the efficiency of the PV water pumping system by converting the high voltage from the DC output of the PV panels to a lower voltage for charging of batteries. The power degradation in PV modules was established to be $0.8 \%$ per year as a result of prolonged field exposure and requires further research [13]. While automatic tracking helped 
in increasing the efficiency, the cost was too high; instead double axis manual tracking systems were suggested to be implemented which helped improve the system efficiency by $20 \%$ and were relatively cheaper. The main factors affecting PV panels were dust accumulation, over heating of PV modules and fluctuation of solar irradiation. To counter the inconsistence in solar irradiation carefully modelled battery systems were suggested to be implemented to ensure economic viability, spraying with water assisted in both dust clearance and cooling of the modules.

Sontake and Kalamkar [9] conducted a comprehensive review of PV water pumping systems encompassing literature from various fields of engineering between the years 1975-2014. The review breaks down the different types of technologies based on site specific designs, site specific performance, performance of the solar pump using different motors, different ratings of PV panels and investigating implement MPPT models. Cost reduction methods were also investigated, and it was found that $60 \%$ of the cost could be reduced by manufacturing PV panels locally. The study also discussed new concepts and design ideas that could be utilised to enhance the effectiveness of the PV panels, reducing the complexity as well as reducing the costs focusing on low capacity PV pumps.

In the review, regions in Africa showed great promise, especially northern and Sub-Saharan African regions, in both Sudan and Egypt PV water pumps was seen to be able to efficiently pump water and provided low operating costs. In Nigeria, the pump performance was seen to be satisfactory providing $20 \mathrm{~m}^{3} /$ day [14]. Research in Algeria also provided positive results concluding that PV water pumps could sufficiently pump water for small scale farm sized under 2 ha [15]. That said, site specific research was proposed, as the performance of pumps was seen to be $10-25 \%$ less than that claimed by the manufacturer [16]. The Various parameters that influence PV pumping technology has been summarised as per Fig. 2 .

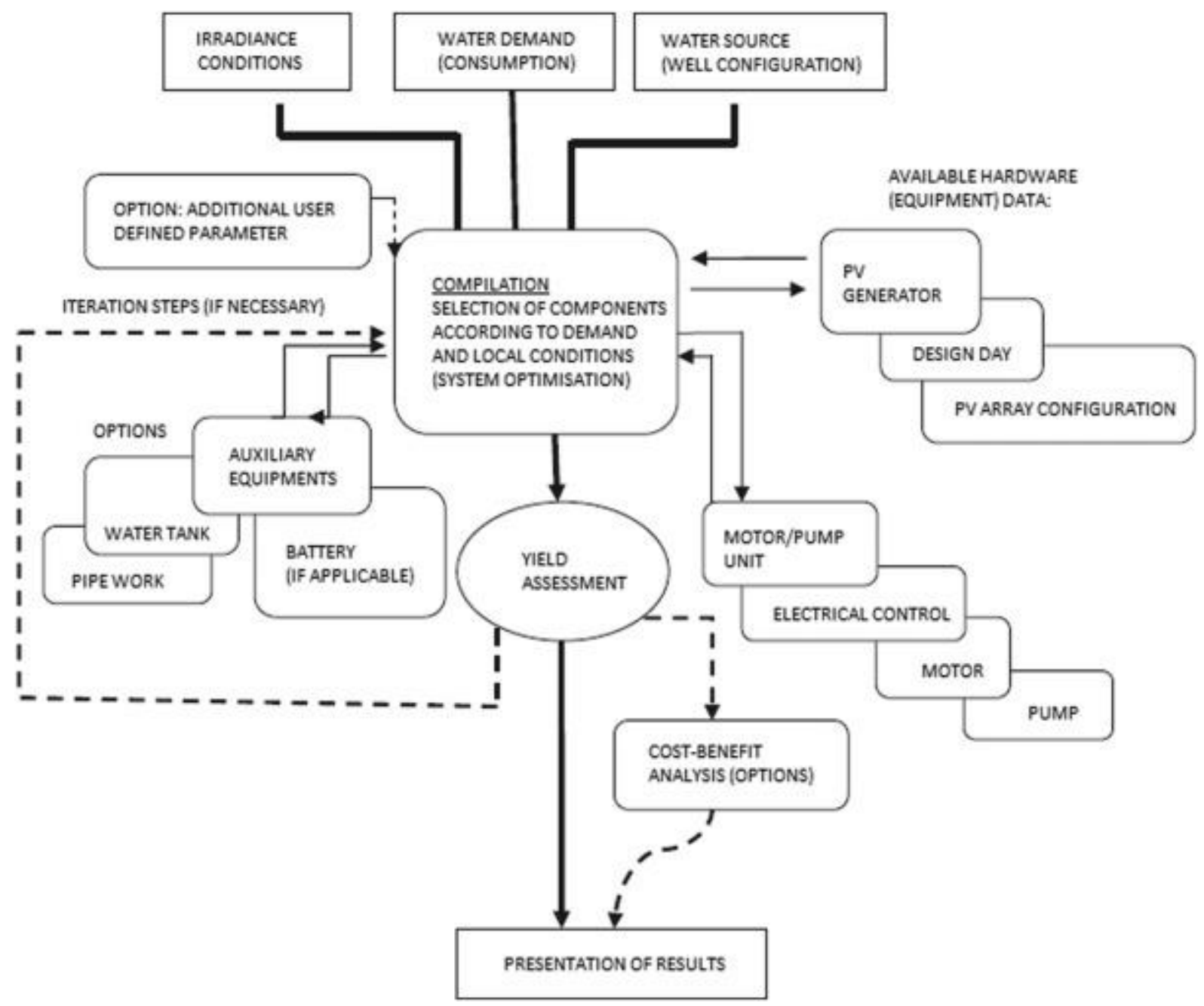


Fig. 2. Parameters that influence PV water pump design [17].

The research estimates a range of optimal power output that can be produced at a solar radiation of $1000 \mathrm{~W} / \mathrm{m}^{2}$, wherein, $1 \mathrm{~m}^{2}$ panel area could produce $100 \mathrm{~W}$, and $17 \mathrm{~m}^{2}$ area could produce $900 \mathrm{~W}$ output. It was also proposed that diaphragm pumps with DC motor be used for small capacity pumps while centrifugal pumps with induction motor would be preferable for higher capacity pumps [9]. Helical pumps were also shown to be suitable for high heads of over 50-150 m with Grundfos 6SQF-2 pump showing no loss after 3 years' performance [18]. DC motors has been the preference for $80 \%$ of the research conducted showing the highest efficiencies with $10 \%$ research showing AC motors providing higher efficiencies for higher capacity pumps, however, the increase in efficiency is minimal. Development in DC motors such as Permanent Magnet Synchronous Motors which are brushless motors and use permanent magnets instead of winding rotors compared to conventional DC motors, further elevates the potential of DC motors.

Research has shown that because of the losses incurred on PV systems, $16 \%$ of the work potential of the PV panels are lost [19]. Few ways to reduce this loss has been proposed including the implementation of tracking, cleaning of panels and cooling of the panels as at higher temperatures the panels show lower efficiencies. Furthermore, computer assisted design has been proposed to optimise the various components of the PV water pump system. Optimisation by implementing MPPT for pumps is shown to increase efficiency by $35 \%$ [20] and water pumped quantity was increased by $7.4 \%$ [21].

Though overheating is an issue boosting with reflectors during days of lower radiation can enhance the power output of the PV system as observed in Fig. 3.

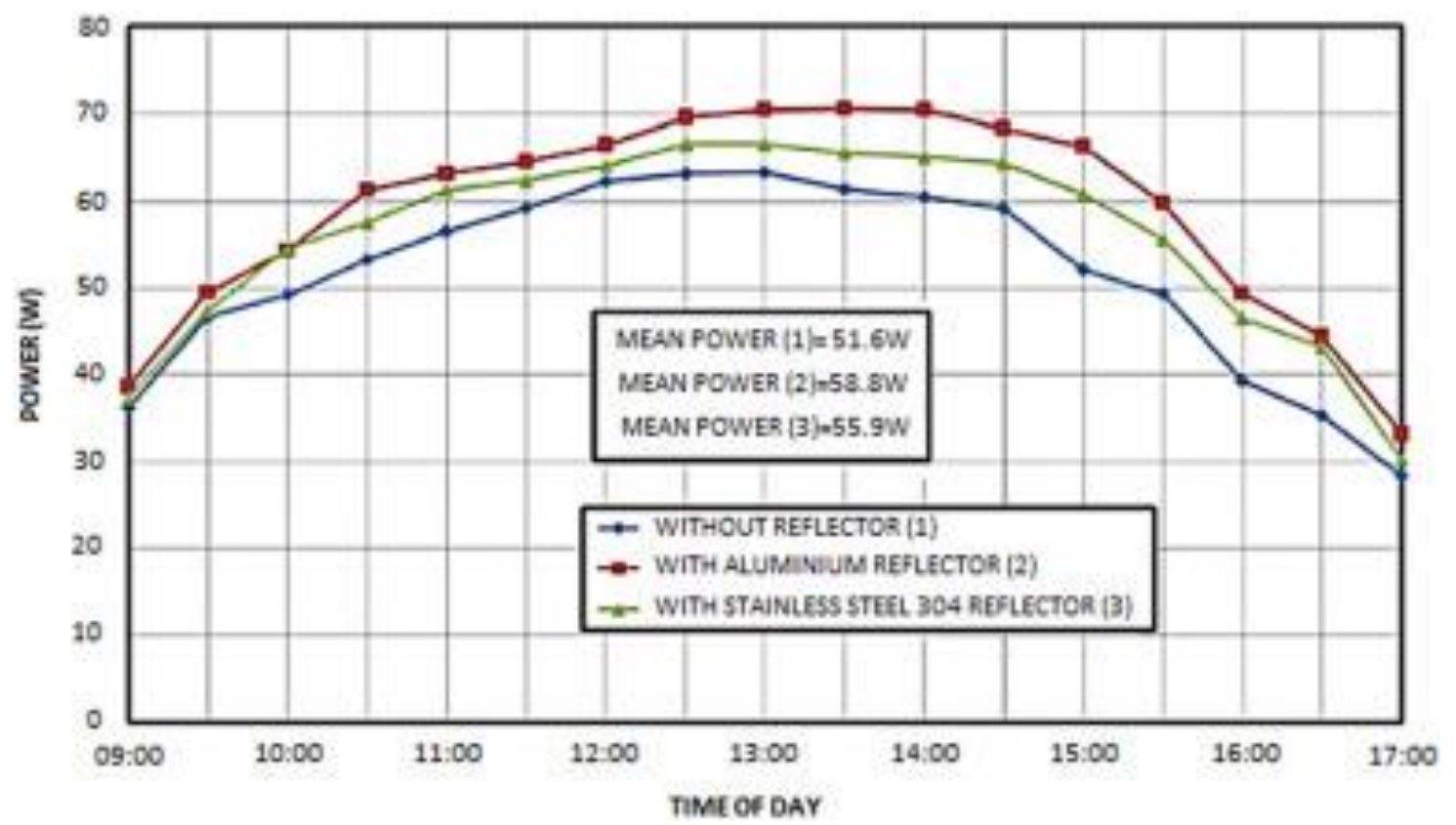

Fig. 3. Power output comparison with and without solar irradiation boost [9].

\subsection{PV irrigation systems}

Deveci et al. [22] designed and developed a drip irrigation system that utilises solar PV power for a project in Turkey covering $1000 \mathrm{~m}^{2}$ and containing over 100 trees, it was considered that it would require $1450 \mathrm{l}$ of water/day. From June to October, the site was irrigated $2 \mathrm{~h}$ a day with the help of an automatic timer. The PV panels (generating $132 \mathrm{Wh} /$ day using two $10 \mathrm{~W}$ PV panels to generate 12 VDC) charged a battery (14 Ah, 12 VDC) buffer throughout the day during available sunlight using Maximum Power Point Tracker (MMPT) to increase the PV conversion efficiency to operate at the maximum power point of the I-V curve. The DC pump was powered by the batteries providing consistent voltage and hence optimal performance of the pump. While other research considers using 
of the battery to drive the cost, Deveci et al. argued that utilising the battery ensures that the overall cost of the system decreases by $63 \%$, thus ensuring better payback and hence making the system cheaper overall. This could allow the use of cheaper PV technology. To better understand of the system characteristics, a context diagram is presented in Fig. 4.

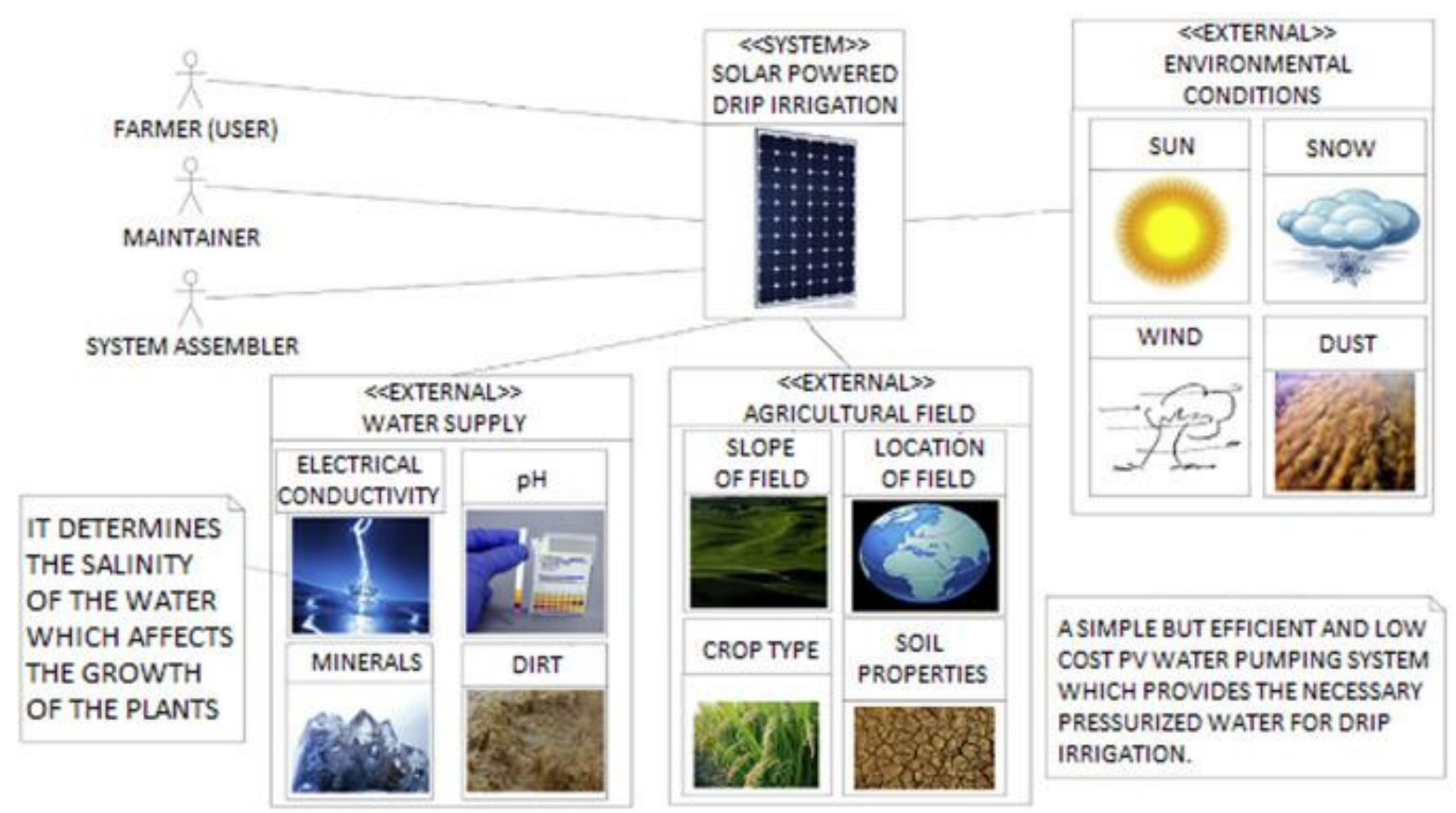

Fig. 4. Context diagram representing drip irrigation system powered by PV [22].

Setiawan et al. [23] designed a PV powered water pumping system to supply water in a village in Indonesia. The systems consisted of 32 panels that produced $3200 \mathrm{Wp}$ and operated 2 submersible pumps (Lorentz PS1800 HR-05HL) to provide a flowrate between 0.4-0.9 1/s and a total head of $218.34 \mathrm{~m}$. The system consisted of 4 stacks of 8 solar cells connected in series, with 2 stack connected in parallel feeding each pump. The pumps are in turn connected in parallel to provide the ultimate head. The Project was funded by Ministry of Research and Technology Republic of Indonesia in conjunction with the Ministry of Public Works however, the costs associated with the system are not indicated. The system designed was optimal in providing clean water to the village where previously the inhabitants would use stored rainwater for survival.

Campana et al. [24] devised a novel optimisation process by which PV water pumping systems could be economically optimised for irrigational purposes. A simulation considering the availability of groundwater, water supply, the investment costs, and the revenue from the crop sale has been developed. To prove the effectiveness of this approach, the simulation is applied to an existing PV water pumping system with the results showed positive impact guaranteeing continuous operation, reducing PV array size and thus reducing the investment and thus lowering the payback period. Nine PV modules, positioned at a tilt angle of $42^{\circ}$ and $-32^{\circ}$ surface Azimuth angle, were proposed to produce $1.44 \mathrm{kWp}$ powering a $1.1 \mathrm{~kW}$ Centrifugal AC pump. However, as per the simulation, due to the low rate of replenishment of the ground water resource, the specifications of the system had to be downgraded to produce $0.96 \mathrm{kWp}$, which in turn decreased $18.8 \%$ of the investment capital. The study enforced the use of natural groundwater level replenishment so that the cost of foraging for water source can be reduced as well as protect the groundwater source from being over used. Fig. 5 demonstrates the relation between annual profits and pump capacity at US\$ $1 / \mathrm{Wp}$ and US\$ $2 / \mathrm{Wp}$ and establishes that with adherence to the ground water level constraints, the most feasible solution is a PV water pump just shy of $1 \mathrm{kWp}$ at US\$1/Wp. 


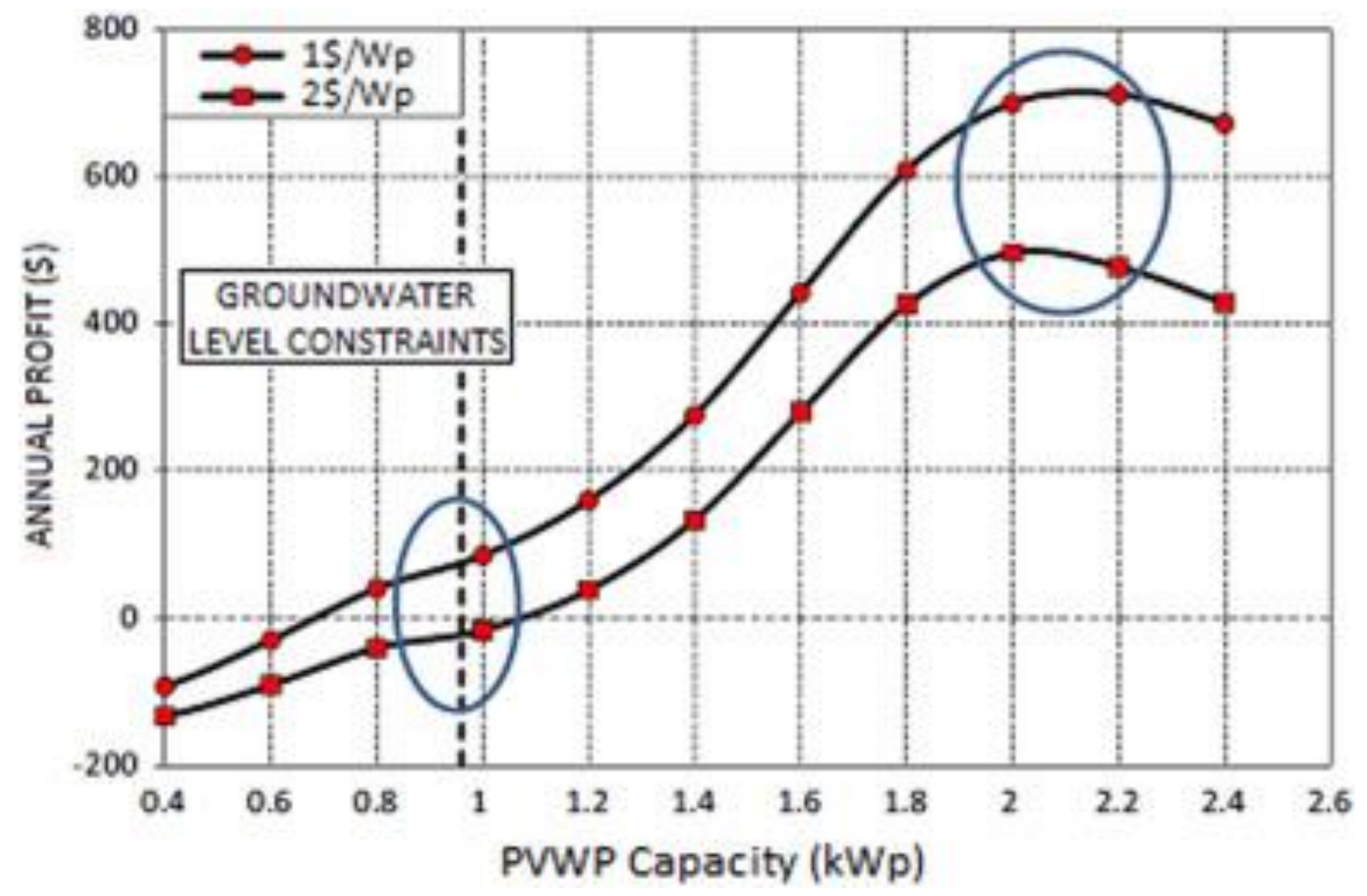

Fig. 5. Pump capacity vs annual profits with constrained groundwater levels [24].

López-Luque et al. [25] proposed a standalone design for a direct pumping PV system for the irrigation of olive orchards optimised with the help of a simulation model for "deficit irrigation" leading to reduction of cost and water savings. The model simulates, the power of the PV system, the balance between energy and water of the irrigation system and the yield of the crop. Using this, the cost of operation of the system and the profit margin was evaluated. The system allowed for a certain level of water stress on the crops if the yield of the crop was not affected. The demand was reduced and thus the system implemented could be cheaper while at the same time saving water. On evaluating a case study in Spain, the optimal power requirement was evaluated as $150 \mathrm{~W} / \mathrm{ha}$ for $40 \mathrm{~m}$ head, $250 \mathrm{~W} / \mathrm{ha}$ for $60 \mathrm{~m}$ head and $300 \mathrm{~W} / \mathrm{ha}$ for $80 \mathrm{~m}$ head for "deficit irrigation" wherein, the plants are irrigated lower than the prescribed amount which requires a thorough understanding of the plant's yield response. For full irrigation, the results were $300 \mathrm{~W} / \mathrm{ha}$ for $40 \mathrm{~m} \mathrm{head,} 400 \mathrm{~W} / \mathrm{ha}$ for $60 \mathrm{~m}$ head and $600 \mathrm{~W} / \mathrm{ha}$ for $80 \mathrm{~m}$ head. The system was found to be feasible for "deficit irrigation" but not full irrigation. "Deficit irrigation" tactics also provided 4-6\% of water saving.

Hossain et al. [26] studied the suitability of utilising solar powered irrigation in Bangladesh for the cultivation of Rice, brinjal (eggplant), tomato and wheat both in the technical and economic sense. Pumps were stationed in 4 different places and the performance of the pumps were tested measuring the solar radiation, voltage and current generated, flowrate and the head. The drip and furrow methods were implemented in the research. Eggplant and tomatoes were tested using both drip and furrow method while wheat was tested using just the furrow method, the method used for rice cultivation was not specified in the study. Around 0.5 ha land was considered for all crops except for rice which was cultivated in a 0.2 ha land. The pump was powered by Solar panel providing between 1050 and 1440 Wp. Considering all four locations, the lifetime profit to cost ratio of utilising the PV powered irrigation system was determined for each crop with tomato, brinjal and wheat shown to be between 2.22-2.34, however, rice was merely 0.31 . This is as per pump cost of US\$ 5700, a life of 20 years and an average discharge of $100 \mathrm{l} /$ minute. $50 \%$ of water was saved using drip irrigation of tomatoes and brinjal. Rice cultivation, however, was not seen as economically viable using PV powered irrigation system method due to the low yield, high water requirement ( 3 times that of the other products). 
Kumar et al. [27] conducted field experiments and testing of a gravity-fed type drip irrigation system powered by solar PV for a small land of $18 \mathrm{~m} \times 6 \mathrm{~m}$ area. The study was conducted in Central India. Water from a pond was pumped to a storage tank $(1000 \mathrm{~L})$ and applied for irrigation as per the Star Configuration irrigation system which contains four micro tube emitters joined at a central connector accessing water from the sub main through another connecting microtube [28]. The pumping system consisted of $148 \mathrm{~W}$ solar panel and a minimum power voltage of $15 \mathrm{~V}$, power current 4-\% A, fitted with a $12 \mathrm{~V}$ battery with a capacity of $10 \mathrm{~A}$ for $5 \mathrm{~h}$, an AC type inverter powering an AC pump of $60 \mathrm{~W}$ drive, input power of $110 \mathrm{~W}$ and discharging at $15 \mathrm{l} / \mathrm{min}$. The overall cost of the set-up was US $\$ 410$ including the cost of solar panels, solar charge control unit, battery with accessories, inverter, pump, overhead tank and civil works. See Fig. 6 for the schematic diagram of the set-up. It was established that this system would be enough to irrigate 0.2 ha of land. As a very small test area was considered, the overall head loss during the conveyance of the water from the storage tank to the crops was almost negligible. The system was recommended to be run between the times of 11 a.m. and 3 p.m. when maximum irradiation could be used and that would be enough for the irrigation needs for a day.

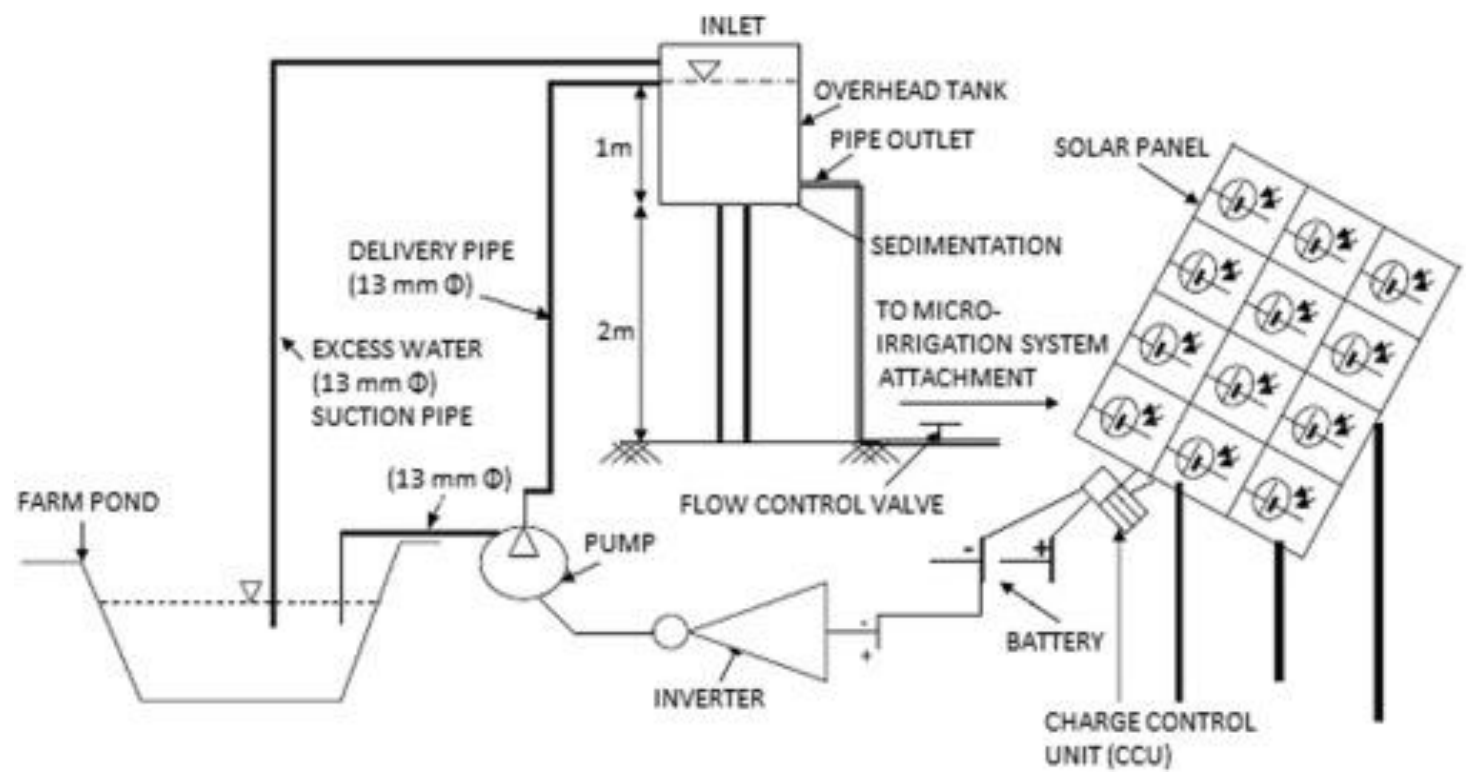

Fig. 6. Schematic diagram of micro-irrigation system powered by solar PV [27].

Reca et al. [29] conducted a feasibility analysis of the profitability of a direct pumping PV system that would work standalone and be used for irrigation in Spanish greenhouses $\left(18{ }^{\circ} \mathrm{C}\right.$ and $3000-3600$ sun hours per year, $0.75 \mathrm{ha} /$ greenhouse, drip irrigation, required 3 1/hour, $40 \mathrm{~m}$ pump head, $8720 \mathrm{~W} / \mathrm{ha}$ ), see Fig. 7. A simulated model comprised of PV power generation, pumping management, and irrigational water requirements was prepared. Several sectors were considered and two strategies of management of irrigational services were established either to irrigate each sector one by one or to group irrigate sectors. The simulation proposed that irrigation of one sector at a time was more profitable than group irrigation, as that would require bigger and more expensive pumps. Profit was obtained by assigning 4 sectors in a hectare, however, the profit margin and efficiency of the system was still low with the highest Net Positive Value (NPV) obtained with 6 sectors, after which the NPV decreased. The profitability of the system could be improved if, the excess produced electricity from the PV panels could be used for other purposes. 


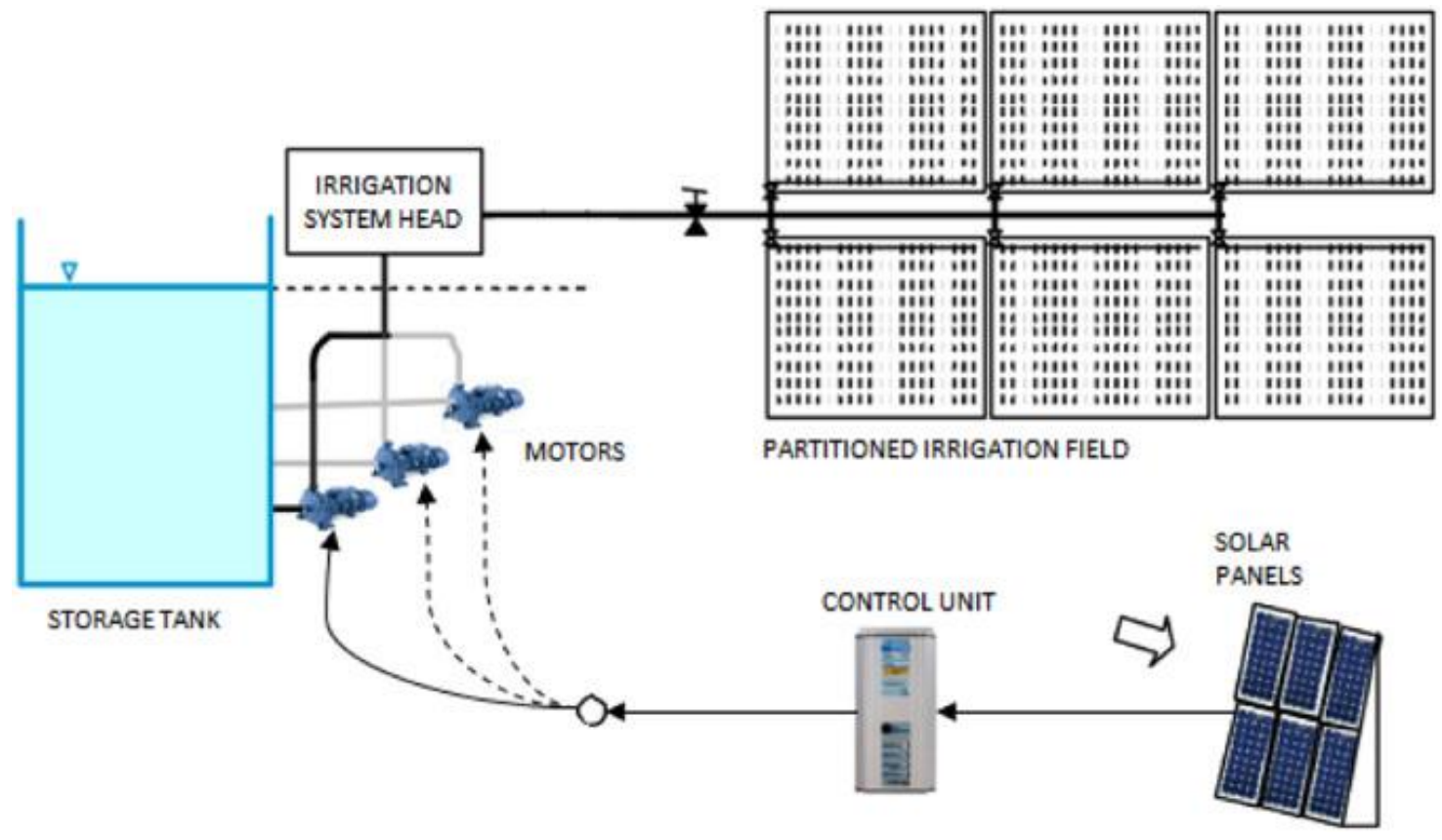

Fig. 7. PV irrigation system management layout [29].

\subsection{PV irrigation systems performance}

Chandel et al. [30] published the analysis of degradation of a mono-C-Si PV module (33 W rated, $1 \mathrm{~m}$ $\times 0.38 \mathrm{~m}$ ) that had been exposed in the field for 28 years In the western Himalayan region of India. The PV module was used for a direct coupled PV water pump and the study's main objective was to identify the impact on the water pump caused due to the PV degradation. Visually the defects identified by the study were discolouration, oxidation of anti-reflective coating and the grid fingers and bubble formation causing delamination in the back sheet. Using a $1 \mathrm{~m} \times 0.38 \mathrm{~m}$ sized PV panel producing $373 \mathrm{~W}$, a head of $10 \mathrm{~m}$ was obtained with a discharge of $5500 \mathrm{l} / \mathrm{h}$. The degradation for this system was measured to be $1.4 \%$ per year using visual, thermal imaging and indoor I-V characteristic measurements of modules under a sun simulator. The results coincided with studies undertaken previously, however, the results showed increase in open current voltage which was expected to reduce, this aspect requires further investigative study.

Yahyaoui et al. [31] modelled the management of an autonomous watering system using "Fuzzy Logic" [32] for energy and water for drip irrigation in a semi-arid district for production of tomatoes supported by PV panels and batteries. The water volume needed by tomatoes was first evaluated during the production cycle across March - July, then the PV panels, batteries and water pumps would be controlled based on the energy availability. The algorithm considered the semi-arid conditions depicted in Tunisia for the irrigation of 10 ha land at $200 \mathrm{~m}^{3} / \mathrm{h}$ before sunrise. Based on the study only $20 \%$ of the required power came from the battery, while $80 \%$ from the PV panels with a control system regulated the usage of power and helped elevate the battery life and increased the overall efficiency of the system.

Rawat et al. [33] reviewed the different ways of modelling and optimisation of size and design methodologies of standalone and grid connected PV water pumping systems in India. A PV system including an array of PV cells, converter, inverter and a battery storage system is considered. To ensure that the PV system performs optimally, equations have been developed for modelling and design methodologies. The study concludes that PV systems are better sized when long term data of the site is available, numerical methods for sizing the PV systems are as good as the data available. In the case of inferior data, more intelligent systems need to be implemented to for better optimisation, such as "fuzzy logic", however these techniques are more complex and would require more expenses. The other factors to efficiently size PV systems are the efficiency curve of inverters, Load management and the motor torque. 
Jones et al. [34] analysed the economics behind the use of PV water pumping at variable speeds in conjunction with a desalination system without the use of energy storage for agriculture. See Fig. 8 for various configurations suggestions of a desalinated water irrigation pump system. For comparison, the PV system was put up against diesel systems and systems utilising energy from the grid. The study was conducted in Jordan and focuses on 15-120 kW size for desalination of water salinity range of 1500 $7500 \mathrm{ppm}$ and at depths of 25-100 m. The study found that using large system sizes greatly reduces the price of desalination with a $15 \mathrm{~kW}$ system costing US\$ $1.55 / \mathrm{m}^{3}$ while a $111 \mathrm{~kW}$ system costing at US\$ $0.7 / \mathrm{m}^{3}$. PV technology was seen to be less economical than grid-powered systems but more economical than diesel powered systems. Furthermore, PV systems was shown to be more profitable for crops that provide high returns and low water consumption, shallow groundwater levels and low salinity levels.

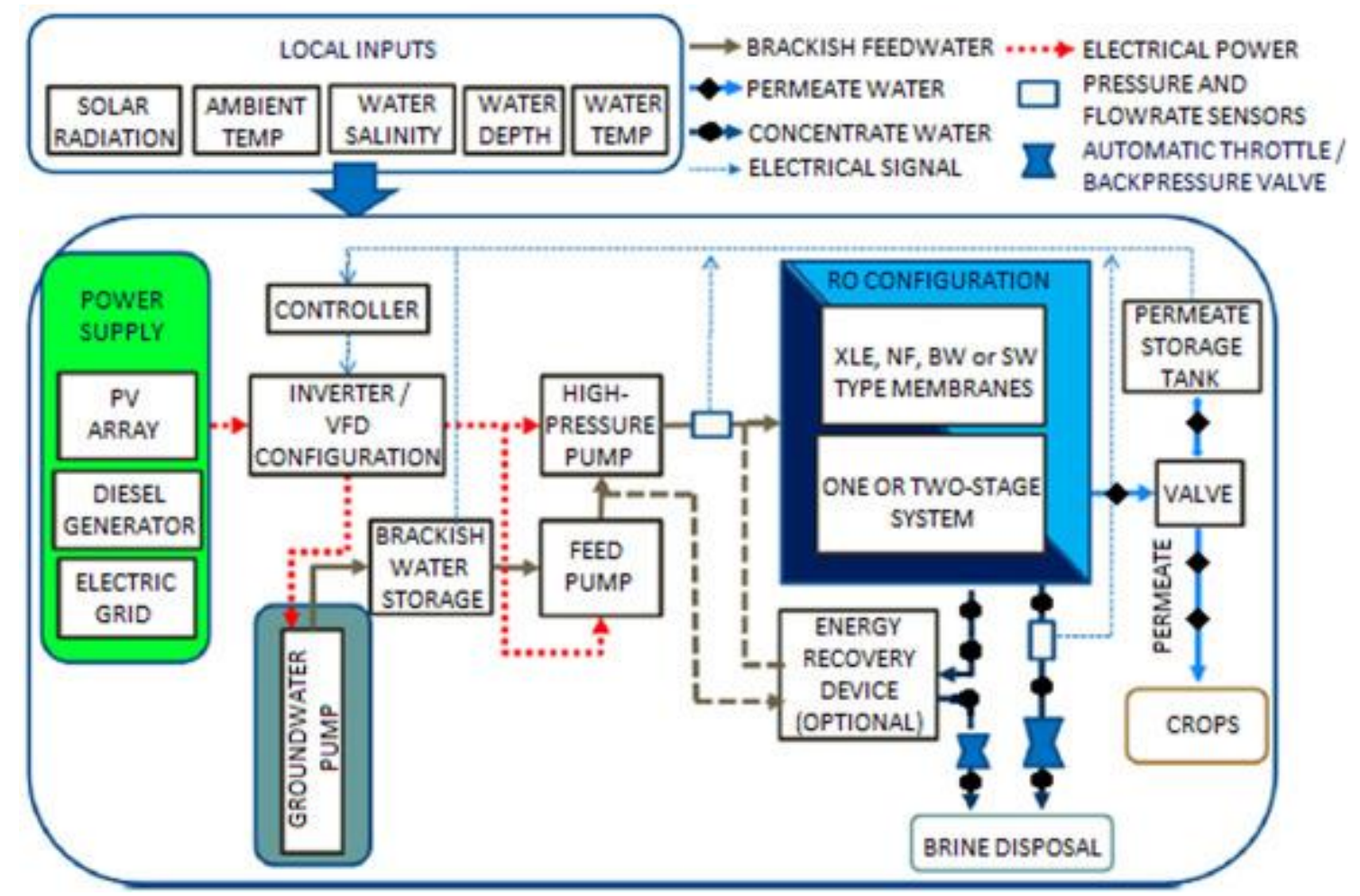

Fig. 8. Various configurations for set up of desalinated water pumping system [34].

Muhsen et al. [7] examined water pumping systems utilising photovoltaic technology featuring the modelling, design procedures, control strategies, field performance, reliability and feasibility of PV systems. Based on the review conducted, the highest system efficiency of 7\% was observed for a system using helical pumps providing 0-8.4 1/min of flowrate in the Amarillo Texas region [35]. The highest average flowrate of 26001 per hour was quoted to be generated for a $990 \mathrm{Wp}$ system in Algeria with $11 \mathrm{~m}$ head giving a productivity of $9498.030 \mathrm{~m}^{3} / \mathrm{kWp}$ per year, the efficiency of the system was $1.299 \%$ without shading and $0.83 \%$ with shading [36]. The most extensive research was conducted on a $3-5 \%$ efficient system with a size of $2 \mathrm{kWp}$ capable of water head of 5-125 $\mathrm{m}$ and was conducted in seven different countries however, this research was done 20 years ago [37]. On average, the overall efficiency of systems is about $3.4 \%$ with an average annual water pumped being $6580.611 \mathrm{~m}^{3} / \mathrm{kWp}$. The study highlighted that the most effective way to size the PV modules is using numerical sizing and control works utilising traditional MPPT.

Campana et al. [38] Investigated the most suitable locations in China where PV water pumping systems could be implemented for irrigation of grasslands. The assessment was made using an optimisation model of renewable energy systems that was spatially explicit based on overall minimisation of cost of the supply chain. The study demonstrated that PV water pumping systems provide a high potential for the improvement of forage productivity to meet the local demand. Land area of 1 ha was considered for a micro irrigation system and a hydraulic head of $20 \mathrm{~m}$ was established powered by a $1.44 \mathrm{kWp}$ PV 
panels [39]. It was established that an increase of $25 \%$ in the yield of forage from grasslands resulted in $300 \%$ increase in the production of forage using PV water pump irrigation systems.

Elkholy and Fathy [40] developed an Artificial Neural Network (ANN) trained by a Teaching Learning Based Optimisation Algorithm (TBOA) [41] to obtain maximum power from solar panels by regulating the inverter voltage and frequency. The TBOA is an algorithm designed on the basis of the teacherstudent relationship of learning to solve continuous and nonlinear functions to find a global optimal solution. The authors modelled an irrigation system that consisted of a PV array $(116 \times 71.3271 \mathrm{~W}$ connected in series) with a three-phase induction motor that drives a centrifugal pump (220/380 V, $1.1 \mathrm{~kW}, 50 \mathrm{~Hz}$ ) for pumping water on MATLAB and Simulink. Based on the simulations undertaken, the efficiency of the system incorporating the ANN-TLBO method was higher than the voltagefrequency control method between 100 and $500 \mathrm{~W}$ power generation, however, over $600 \mathrm{~W}$ generation, the efficiencies of methods were closer.

Closas and Rap [42] investigated the impacts, opportunities and limitations of PV powered water pumping systems that utilise ground water reserves. The authors show that most projects overlook the true financial and economic costs of the technology and the use of the water resources which adversely affects the environment negatively. The study insists that link between water, energy and food must be balanced and this can only be possible when accurate data is provided. Monitoring of Ground water is deemed paramount so that the sustainability goals of the technology is met and the livelihood of the future inhabitants are not threatened. The data obtained would be used not only to design the adequate irrigation system, but also can assist in regulation of subsidies and thus avoid "market distortions". The paper has adequately described key aspects often overlooked when new irrigation technology is being developed this is true for every irrigation system, however, the authors have focused only on PV powered systems.

\subsection{PV irrigation technology in comparison to other technologies}

Campana et al. [43] discussed the technological and economic feasibility of renewable energy systems for irrigation and conservation of farmlands in China, comparing PV water pumping technology to wind powered water pumping systems. Based on the irrigation water requirement (calculated as per FAO [44]), a model was developed to calculate the size of PV and wind powered systems based on varying solar irradiation and wind speeds respectively. A storage system or battery was considered as they are shown to impact adversely to the cost. The alfalfa plant was considered for the simulation model which has a plant density of 75,000 plants per hectare, 90\% canopy cover, growing between May to September (140 days). The PV system produced a capacity of $2.9 \mathrm{kWp}$ (at $2 \$ / \mathrm{Wp}$ ) while wind power generated $2.6 \mathrm{kWp}$ (at $5.5 \$ / \mathrm{Wp}$ ) to power a $2.2 \mathrm{~kW}$ pump with the $\mathrm{PV}$ water pump irrigated land having higher produce than that irrigated with wind power. The study established that depending on the site wind powered systems can compete with PV systems, however, PV systems overall have more potential and better performance.

Treephak et al. [45] conducted an economic evaluation to compare PV powered and gasoline powered water pumping systems for irrigation and cultivation of rice. A 1.6 acre of land irrigated for 25 years was considered for the analysis and the fuel cost required for the pumping of water for the cultivation of rice is considered. With the same conditions, PV powered systems consisting of PV panels along with four different configurations are analysed including, AC motor without battery (S1), DC motor without battery (S2), AC motor with battery (S3) and DC motor with battery (S4). See Table 2.

Table 2. Economic analysis of different PV systems [45].

\begin{tabular}{|c|c|c|c|c|c|c|c|}
\hline \multirow{2}{*}{ Scenario } & \multicolumn{2}{|c|}{ Motor size (W) } & \multirow{2}{*}{ Battery } & \multirow{2}{*}{ Inverter $(\mathrm{W})$} & \multirow{2}{*}{ Solar panel } & \multirow{2}{*}{ Estimated cost } & \multirow{2}{*}{ Payback period (years) } \\
\hline & $\mathrm{AC}$ & DC & & & & & \\
\hline S1 & 750 & - & - & 1500 & $250 \mathrm{~W}(\times 6)$ & $\$ 2800$ & 10.1 \\
\hline
\end{tabular}




\begin{tabular}{|c|c|c|c|c|c|c|c|}
\hline \multirow{2}{*}{ Scenario } & \multicolumn{2}{|c|}{ Motor size (W) } & \multirow{2}{*}{ Battery } & \multirow{2}{*}{ Inverter $(\mathrm{W})$} & \multirow{2}{*}{ Solar panel } & \multirow{2}{*}{ Estimated cost } & \multirow{2}{*}{ Payback period (years) } \\
\hline & $\mathrm{AC}$ & $\mathrm{DC}$ & & & & & \\
\hline $\mathrm{S} 2$ & - & 500 & - & - & $250 \mathrm{~W}(\times 4)$ & $\$ 2000$ & 7 \\
\hline $\mathrm{S} 3$ & 375 & - & $85 \mathrm{Ah}(\times 4)$ & 1200 & $295 \mathrm{~W}(\times 4)$ & $\$ 2800$ & 13.5 \\
\hline S4 & - & 250 & $60 \mathrm{Ah}(\times 4)$ & - & $295 \mathrm{~W}(\times 3)$ & $\$ 2200$ & 9.3 \\
\hline
\end{tabular}

Treephak et at. shows that stirring away from a gasoline powered system, the solar panels would save US \$280 every year of fuel cost. From the analysis, a DC motor system without battery provides the highest economic value.

Sarkar and Ghosh [46] presented a techno-economic analysis of solar powered pumps in Bangladesh. They also provided a list of 108 functioning solar PV pump systems across Bangladesh as an initiative by Infrastructure Development Company Limited (IDCOL). The authors compared PV technology with diesel generators. For a PV system between 0.1 and $20 \mathrm{~kW}$ the PV array cost will be US\$1000/kW, Inverter cost of US $\$ 500 / \mathrm{kW}$ and Battery cost of US\$300/kW compared to US\$ 600/kW for Diesel. For maintenance, the study suggests that the diesel generator system would cost US\$ 438/year compared to US\$ 80/year for the PV system. The payback period of the PV system was calculated to be 9.33 years producing a benefit to cost ratio of 1.08 . The authors have not provided a parallel calculation for the Payback period of a diesel system which may have shown a better comparison, however, a greenhouse gasses (GHG) reduction analysis has been conducted showing that there is a net reduction of $0.865237 \mathrm{t}$ of $\mathrm{CO}_{2}$ using a PV powered system when compared to diesel system. The GHG analysis however only considers operational emission hence sighting GHG emissions of Solar PV system to be zero.

Gopal et al. [8] conducted a review encompassing different renewable energy source water pumping systems for water pumping including solar PV, solar thermal, wind energy, biomass and hybrid renewable energy systems. The paper describes the limitations of each system and identifies further research that can be undertaken.

With respect to PV technology, a payback period of 6 years was calculated, sustainable for domestic applications up to "medium head" requirements. In drip irrigation applications, it was observed that PV technologies was more effective especially in rural areas, for grassland conversation and small scale irrigation applications. The potential of PV panels to be able to considerably reduce the $\mathrm{CO}_{2}$ emissions over its 25 years of operation is also envisaged [47].

The main issues that plague PV technology are its affinity to be affected by the intensity of solar radiation, the change in temperature and the velocity of water flow. Energy storage costs are also identified to be very high however, use of a storage tank boosts the performance. One fact the review admits that needs to be addressed is the environmental impact that PV panel manufacture process has, which would be higher for systems using battery for storage. The environmental impact is measured by energy payback time and greenhouse gas emissions. See Table 3.

Table 3. Environmental impact of different types of PV cell types [8].

\begin{tabular}{llccc} 
Type of cell & $\begin{array}{l}\text { Energy } \\
\text { timea }(\text { years })\end{array}$ & $\begin{array}{c}\text { payback } \\
\text { eq./kW h) }\end{array}$ & $\begin{array}{l}\text { Greenhouse } \\
\text { eqmissions }\end{array}$ & $\begin{array}{c}\text { (g-CO2- Lifetime } \\
\text { (years) }\end{array}$ \\
\hline Mono crystalline & 2.5 & 50 & N/A \\
Multi crystalline & 2.0 & 43 & N/A \\
Cadmium telluride & 1.5 & 48 & 20
\end{tabular}




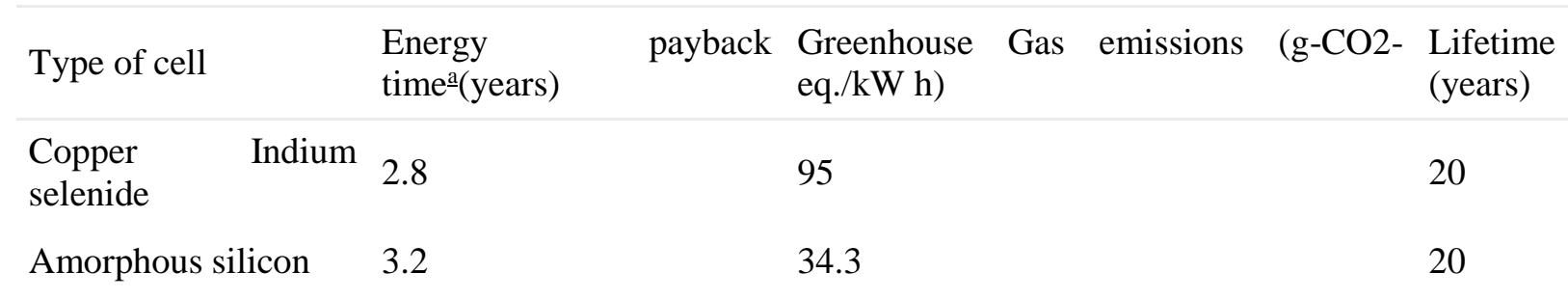

Energy payback = energy used for manufacture and set up divided by energy produced.

Cadmium telluride PV cells have been shown to have the best environmental impact with the smallest carbon footprint and payback period in comparison to all solar PV technologies [48]with the highest module efficiency of 19.6\% [49]. In comparison PV technology is seen 10 times safer than coal fired plants but 4 times higher in comparison to Nuclear and wind turbine power plants [8]. The average Global warming Potential for $1 \mathrm{kWh}$ of electricity is seen consistently higher as calculated from previous literature is $0.078 \mathrm{kgCO}_{2}$-eq for $\mathrm{PV}$ technology, whereas both Nuclear and Wind produce 0.02 $\mathrm{kgCO}_{2}$-eq [50].

Solar thermal technology, on the other hand, had very less research undertaken and not commercialised due to its low conversion efficiency. Two types of technologies were discussed including, one using vapour power cycles (Rankine Cycle) and the methyl hydride systems. The system efficiencies of vapour powered cycles were very poor ranging from between $0.12 \%$ to a maximum of $3 \%$ for a $1 \mathrm{~m}^{2}$ flat collector aperture area working between heads of 6-15 m pumping between 1701 per day to $14001 \mathrm{per}$ day with the highest operation values observed for lower heads during the summer using R113 as the working fluid [51].

Water pumping systems using Methyl Hydride could provide higher output at 20001 per day using a $1 \mathrm{~m}^{2}$ solar collector up to $15 \mathrm{~m}$, but even then, the efficiency was 1.5\% [52]. The authors establish that due to the low conversion efficiencies, high costs and environmentally unsafe working fluids; solar thermal technologies fall short of PV irrigation technologies.

Gopal et al. identifies that PV, wind and a hybrid system utilising PV and wind will best suit conditions in India when compared with Diesel technologies. Even though the initial investment for PV hybrid is 9 times more than that of Diesel, the Operational and maintenance costs of diesel is 80 times more than that of PV technologies making it economically feasible for the region [8].

\section{Solar thermal systems}

Solar thermal systems obtain thermal energy from the sun via a solar collector or a solar concentrated surface. The energy is then transferred via a fluid or directly to either a Rankine, Brayton or Stirling Cycle engine which then converts the thermal energy into mechanical work. The mechanical work produced can be used directly to power pumps, converted to electrical energy for storage, or for powering an electrical pump. Fig. 9 shows a schematic of a solar thermal powered irrigation system. Obviously, direct utilisation of the mechanical power is desired, however, storage of thermal energy is a much more difficult proposition when compared to the storage of electrical output. 


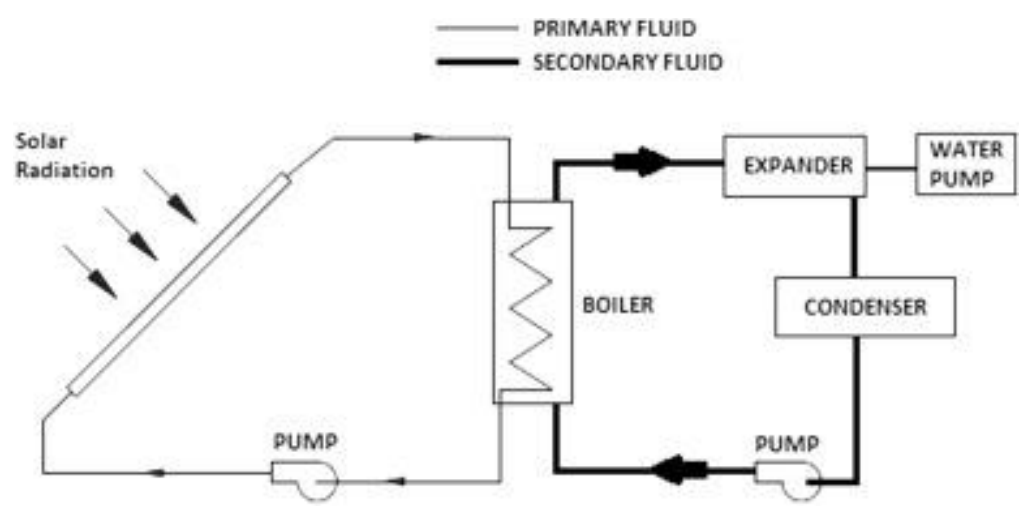

Fig. 9. A typical Rankine cycle solar thermal pumping system [8].

Most of the research on solar thermal powered irrigation system utilises the Rankine Cycle system or variations of the same. In this system, a working fluid is circulated through a system of boilers, expanders and condenser. The fluid is initially evaporated at the boiler by obtaining heat from a source, in this case solar thermal energy, it then passes through an expansion device (for example a turbine) which generates the power output and then is condensed to complete the cycle [8]. Rankine cycle systems have demonstrated very low thermal efficiencies (around 1\%) and high cost associated with initial investment, maintenance and working fluids [9]. Furthermore these systems require a significantly larger land space to work with and is very difficult to leakproof the system [8]. These issues have affected solar thermal irrigation research in the recent years, especially as more and more emphasis is being given to the irrigation of smaller farm spaces making this technology unfeasible.

Recently, however, research on medium to low temperature Stirling engines coupled with commercial interest due to the simple construction of Stirling systems has been successful in elevating the technology. Fig. 10. shows a schematic of a Stirling cycle thermal powered irrigation system. A Stirling engine produces mechanical work by utilising cyclic compression and expansion of a working fluid (air, helium, hydrogen, nitrogen) [53] operating at different temperatures and enclosed in a fixed space [54]. The Stirling Engine can achieve the closest efficiency to the ideal Carnot cycle when compared to any other engines [55]. The efficiency of Stirling Engines are calculated to be between 30$40 \%$ for maximum operating temperatures up to $923-1073 \mathrm{~K}$ at operating rates between 2000 and $4000 \mathrm{rpm}[56]$. 


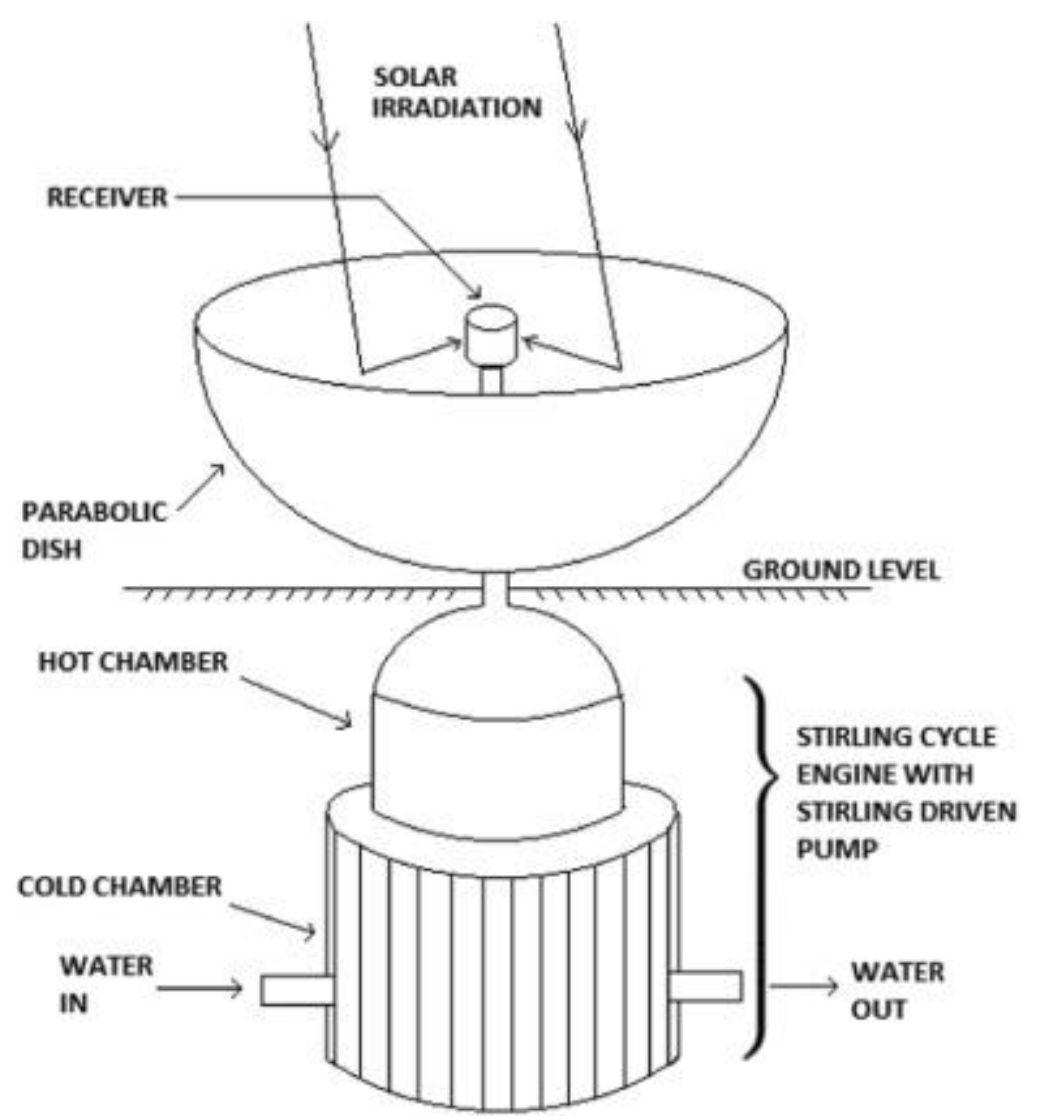

Fig. 10. An example of a Stirling cycle thermal power irrigation system.

There are three major types of Stirling Engines, $\alpha, \beta$ and $\gamma$ type differentiated by it's configuration. The $\alpha$-type engine has two piston contained in hot and cold cylinders, the $\beta$-type engine has 1 cylinder containing a power piston and a diaphragm while the $\gamma$-type engine is similar to the $\beta$-type engine but houses the power piston separately. $\gamma$-type systems have the highest thermal efficiency when compared to the other two systems. Variations of the $\gamma$-type engine are the free piston engine and the Fluidyne pump [55].

Unlike PV technology, solar thermal technologies for pumping water has not been widely researched in the last 10 years. In fact, no papers were found between 2006 to 2008.

\subsection{Solar thermal irrigation technology reviews}

Delgado-Torres [57] provided a review of solar thermal heat engines for water pumping. He classified the technologies into two types, conventional and unconventional. Solar energy was first converted into Mechanical energy either by a power cycle or the adsorption/desorption cycle, the mechanical energy was then either converted into electrical energy to be used for a conventional pump or used directly with an unconventional pump design. Among the conventional methods, the Rankine cycle systems were discussed. Rankine systems generally used water as the working fluid, but as time went on various other fluids were used either on their own or sometimes in conjunction. The working fluids tested included, water, sulphur dioxide, ether, chlorobenzene, R11, R113 and HT-43. Flat plate and parabolic collectors were the preferred collector systems as per the research undertaken, however there was also research undertaken on conical reflectors, truncated cones, and wooden boxes with reflector plates.

The largest Parabolic trough collector project was in Egypt in 1913 that used a $60 \mathrm{~m}$ long and $4 \mathrm{~m}$ wide parabolic trough to pump $27 \mathrm{~m}^{3} / \mathrm{min}$ and delivered $40.42 \mathrm{~kW}$ maximum power output [58]. In 1976, in Mexico, a flat plate collector spanning about 2.5 ha included a vapour powered turbine that was used to generate electricity to produce $1000 \mathrm{~m}^{3} /$ day [59]. The largest parabolic dish installation was made in India in 1987 that used 6 collectors with 9 m diameter each to produce steam at $500{ }^{\circ} \mathrm{C}$ at $7 \mathrm{MPa}$ to 
drive a steam engine rated at $20 \mathrm{~kW}$ which was then connected to an irrigation system [60]. The wooden box with reflector plates was also an interesting project, that spanned over $1000 \mathrm{~m}^{2}(1 \mathrm{ha})$ land area and produced a mean daily power output between $10.29-11.76 \mathrm{~kW}$ and a maximum power output of 17.64$23.52 \mathrm{~kW}$ generating a discharge of $11.3-12 \mathrm{~m}^{3} / \mathrm{min}$ across a head of $10 \mathrm{~m} \mathrm{[58].} \mathrm{Among} \mathrm{the} \mathrm{smaller}$ systems, included a truncated cone with $10 \mathrm{~m}$ diameter at the top and $4.5 \mathrm{~m}$ diameter at the bottom which could provide $7.35 \mathrm{~kW}$ driving a pump to discharge at $6.4 \mathrm{~m}^{3} / \mathrm{min}$ of power by generating steam at $1.03 \mathrm{MPa}$ from a $5 \mathrm{~m}$ depth [58].

Most of the conventional systems discussed were too large in size and required a big financial investment. Moreover, the Rankine systems is very complex and would require a lot of maintenance dealing with intricate pipe work, boiler and turbines. The author discussed three distinct alternative methods that could be used to make the technology viable for small scale use. Among the unconventional methods for water pumping, the author discusses three distinct categories which are, vapour cycle systems, liquid piston systems and metal hydride systems. Vapour cycle systems use a simple displacement pump with the water being displaced by steam/ethyl/pentane vapour. A $1 \mathrm{~m}^{2}$ area flat plate solar collector using such a vapour cycle was able to provide a flow of 336 1/day at $6 \mathrm{~m}$ head, $250 \mathrm{l} /$ day at $8 \mathrm{~m}$ head and $17 \mathrm{l} /$ day at $10 \mathrm{~m}$ head [61].

Liquid pistons is a variation of free piston Stirling engines in which the solid pistons is replaced with liquid to allow lower levels of friction and air tightness, see Fig. 11. The Fluidyne pump is an example of such a system where air is heated and cooled and causes a U-shape liquid column to oscillate and thus cause lifting and suction. In the laboratory, the Fluidyne systems have been able to provide up to $3 \mathrm{~kW}$ of power at a temperature difference of $95^{\circ} \mathrm{C}$ and pressure of $160 \mathrm{kPa}$ and giving $2 \mathrm{~m}^{3} / \mathrm{h}$ pump capacity [62].

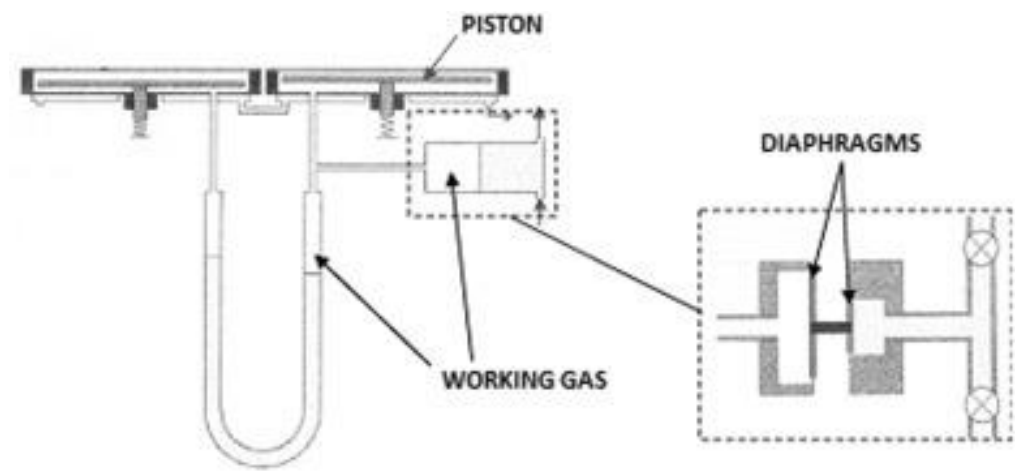

Fig. 11. Liquid Piston pump design using diaphragms [57].

The final unconventional method discussed in the paper was using the metal hydride. In this system, metal hydride is subjected to heat causing release of hydrogen, as hydrogen is released the pressure is increased pressing down on the piston. Once the piston reaches the bottom of the cylinder, the metal hydride is then cooled, lowering the pressure and leading to the absorption of hydrogen. The system studied worked on the basis of heating and cooling of the metal hydride that could be controlled by a flat plate collector and the water flow generated by the pumping process respectively. A test on a metal hydride system was conducted in Kolkata in 2004 using a $1 \mathrm{~m}^{2}$ flat collector at a tilt angle of $15^{\circ}$. On a clear day, a maximum of $2000 \mathrm{l}$ of water was pumped to a height of $15 \mathrm{~m}$ and on a cloudy day $500 \mathrm{lof}$ water was pumped. In terms of metal hydride use, on a clear day $240 \mathrm{l} / \mathrm{day} / \mathrm{kg}$ of metal hydride is used while on a cloudy day it is about 60 1/day/kg [52]. The set-up of the system is shown in Fig. 12 


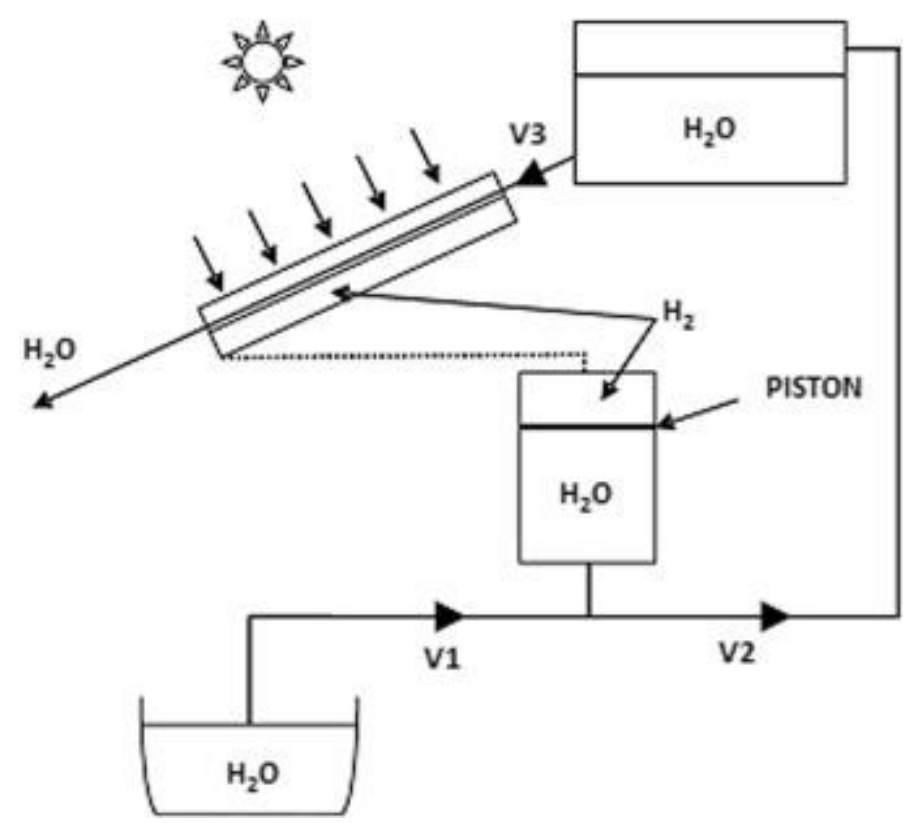

Fig. 12. Metal hydride based solar thermal water pumping system design [52].

The issue with unconventional systems is that the power output of the systems is much lower than those systems using the conventional methods. Added to this the operational costs of metal hydride systems is high as well. However, unconventional systems have the advantage of being used in difficult to access rural areas and the relatively smaller scale systems. This could allow even small scale farmers can benefit from a feasible and viable technology. The classification of conventional and unconventional technologies as established by Delgado-Torrez shall be followed in this paper.

\subsection{Conventional solar thermal technologies}

Lakew et al. [63] conducted a thermodynamic analysis of a low temperature $\left(60{ }^{\circ} \mathrm{C}\right)$ heat source Rankine cycle functioning in conjunction with a thermal driven pump with supercritical carbon dioxide as the working fluid. A shell and tube heat exchanger (diameter $=5 \mathrm{~mm}$ ) functioned as the thermal pump removing the need of a mechanical driven pump and thus reducing the maintenance. A continuous source of heat was required for this system. The study showed that a Rankine cycle operating with a thermal driven pump had higher power generation capability than conventional Rankine cycle but an additional low temperature heat source was required for this process. Hence in this method, there was a requirement for a heat source for the boiler $\left(100{ }^{\circ} \mathrm{C}\right)$ as well as a heat source $\left(60{ }^{\circ} \mathrm{C}\right)$ for the pump. While the heat source for the boiler was the same in both the thermal pump driven Rankin cycle and the mechanical pump driven Rankine cycle, the thermal pump did not require maintenance, had lower noise levels and vibration and maintained a lower rate of efficiency deterioration when compared to mechanical pumps. However, in terms of cost it was more expensive due to the requirement of heat exchangers.

Tchanche et al. [64] reviewed the various applications of using organic Rankine cycles for generating power from low-grade heat. The study considers co-generation systems, water heat recovery systems, desalination systems as well as solar thermal power systems. Organic Rankine cycles utilised refrigerants and hydrocarbons as the working fluid instead of water as Rankine cycles using water were more complex and utilised expensive turbines which are also at high risk of erosion. Furthermore, water needs to be superheated so that during expansion the water does not condense which in turn means there is excess pressure in the evaporator. The authors listed the temperature ranges and concentration ratios of different collector systems as per Table 4. Dish concentrators provided the highest temperatures with the least footprint. Without a tracking system Evacuated tube collectors and parabolic collectors are shown to have the highest concentration ratios.

Table 4. Range of temperature and ratio of concentration of various solar thermal systems [64]. 


\begin{tabular}{llll}
\hline Technology & $\mathrm{T}\left[{ }^{\circ} \mathrm{C}\right]$ & Concentration ratio & Tracking type \\
Air Collector & $0-50$ & 1 & - \\
Pool Collector & $0-50$ & 1 & - \\
Reflector Collector & $50-90$ & - & - \\
Solar Pond & $70-90$ & 1 & - \\
Solar Chimney & $20-80$ & 1 & - \\
Flat Plate collector & $30-100$ & 1 & - \\
Advanced Flat Plate Collector & $80-150$ & 1 & - \\
Combined heat and power solar Collector & $80-150$ & $8-80$ & - \\
Evacuated Tube Collector & $90-200$ & 1 & 1 -axis \\
Compound parabolic collector & $70-240$ & $1-5$ & 1 -axis \\
Linear Fresnel Reflector & $100-400$ & $8-80$ & 2 -axis \\
Parabolic trough & $70-400$ & $8-80$ & 2-axis \\
Heliostat field + Central Receiver & $500-800$ & $600-1000$ &
\end{tabular}

One of the more comprehensive systems discussed in the study included an Organic Rankine Cycle system consisting of a $60 \mathrm{~kW}$ propane boiler, compact brazed heat exchanger, air compressed diaphragm pump, radial flow turbine at 65,000 rpm and a high-speed actuator working at relatively low temperatures between $93{ }^{\circ} \mathrm{C}$ in the inlet $\left(81^{\circ} \mathrm{C}\right.$ at the evaporator) and $38{ }^{\circ} \mathrm{C}$ at the condenser with $\mathrm{n}$ Pentane as the working fluid producing a mass flowrate of $0.1 \mathrm{~kg} / \mathrm{s}$, power output of $1.44 \mathrm{kWe}$ and costing US $\$ 25,880$ with $37 \%$ of the cost attributed to the cost of the turbine-generator [65]. The other systems discussed, used different mid to high range collector systems and tested various types of working fluids. Hybrid systems with collectors and gas/diesel burner systems were also considered.

Solar Ponds were also discussed with large to medium size power plants shown to be constructed and operated in Israel, Australia and the USA. Systems working on the principal of Organic Rankine Cycle for pumping of water for desalination and distribution were also studied but the size of these systems were large for consideration for small scale irrigation.

Low grade conversion systems investigated in this paper were investigated specifically for ocean thermal energy conversion to function offshore at low temperatures and function as a total resource system. These systems are good for off the grid power solutions for remote areas, however, the size and costs associated with the systems will be viable only if the technology is implemented on a community level and not individual level.

Baral et al. [66] performed a thermo-economic analysis and experimentation of a small-scale organic Rankine cycle system that was powered by solar energy for power generation in rural areas. The power output from the designed system ranged between $400 \mathrm{~W}$ and $1.38 \mathrm{~kW}$ during the year with the maximum output in April. The system is a typical organic Rankine cycle system using refrigerant R245fa as the working fluid and 15 evacuated tube solar collectors would provide hot water $90{ }^{\circ} \mathrm{C}$ to $120^{\circ} \mathrm{C}$. see Fig. 13. The selling cost for the technology was found to be US\$ 0.68 and at that price the payback period is 19 years for operational components most of which have a life time of 20 years. This has been calculated as per the prototype tested, however, a subsidised development programme can 
assist in fine tuning the technology and thus reducing the cost of the technology. Even then, the technology would not be suitable for independent small scale farmers.

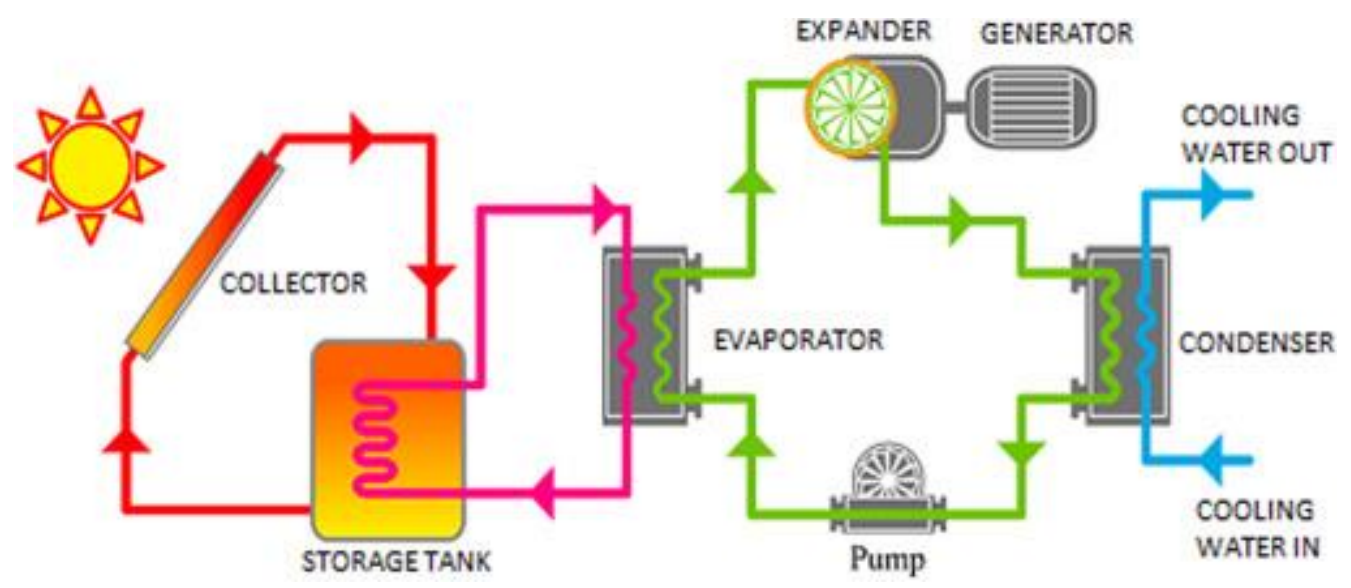

Fig. 13. Solar powered organic Rankine cycle system [66].

Baral and Kim [67] analysed the economic viability of a standalone organic Rankine cycle system that functions on solar thermal energy to pump water for drip irrigation in rural Nepalese area. The authors performed experiments based on a prototype and analysed the economic viability of the system based on the solar radiation data described in Fig. 13. Economic assessments were carried out for $1 \mathrm{~kW}$ and $5 \mathrm{~kW}$ systems and the cost of hot water $\left(\right.$ at $40{ }^{\circ} \mathrm{C}$ ) was shown to be between US $\$ 1.86 / \mathrm{m}^{3}$ and US\$ $2.47 / \mathrm{m}^{3}$ for a $1 \mathrm{~kW}$ system and $150 \mathrm{~m}$ pumping head pumping $2190 \mathrm{~m}^{3}$ per year, while the $5 \mathrm{~kW}$ system pumped $11,100 \mathrm{~m}^{3}$ per year. Increasing the size of the system and decreasing the pumping head was shown to reduce the cost generating a profit index of 1.6 with a payback period of 8 years at the above costs of selling water. Such a system is viable for a rural community service but not for independent small scale farmers.

Moonsri et al. [68] designed a thermal water pump functioning on hybrid energy input for pumping water from a shallow well to produce hot water in Thailand. The systems consisted of a $2.1 \mathrm{~m}^{2}$ solar collector at an inclination of $14^{\circ}$ made of copper plates and tubes and a $2000 \mathrm{~W}$ electric heater to work in conjunction with the solar collector to produce steam coupled with a system described in Fig. 17 based on research conducted by Sitranon et al. [69]. The system could pump 2151 of water up to $3 \mathrm{~m}$ height working on $6.5 \mathrm{MJ}$ of power from the hybrid system. The study compares the system with a solar PV powered system. Though the comparison was not conclusive, it identifies various maintenance issues with the hybrid system including the erosion of rubber seals, valves and heat loss. PV systems disadvantages are highlighted in terms of performance loss at high temperatures, expensive battery and the environmental impact of producing PV panels.

Bataineh [70] investigated the performance of a water pumping systems powered by solar thermal energy. Recent developments in solar thermal systems were also presented and methodologies to further enhance the energy conversion were proposed. Set in Jordan, a system working on the principal of the Rankine cycle in conjunction with parabolic trough collector was studied using mathematically simulate models. Considering a $526 \mathrm{~m}^{2}$ collector area, producing $30 \mathrm{~kW}$ energy, 20 years of operational life of the system, $6 \%$ maintenance cost per year, US $\$ 250 / \mathrm{m}^{2}$ being the cost of the solar field and US\$ 60,000 the cost of the steam turbines, the cost of solar energy amounts to US $\$ 0.075 / \mathrm{kWh}$ which in comparison to diesel is $0.082 / \mathrm{kWh}$. While the technology is more cost effective than diesel generated, it is still more expensive than PV and requires a large area. The investment cost is also very high making it unsuitable for rural areas.

\subsection{Unconventional solar thermal technologies}

Mahkamov and Orda [62] performed a preliminary analysis of the working process of solar thermal water pumps designed similar to a free-piston Stirling Engine. The system uses a fluid piston that claims 
to overcome issues of instability that were faced by conventional fluid piston pumps by including a new diaphragm setting and reducing the dead space in the hot cylinder, cold cylinder and regenerator. They discussed in their paper that solar thermal water pumps were low maintenance and low cost systems that could provide pumping capacities of $0.2-1 \mathrm{~m}^{3} / \mathrm{h}$ and a dynamic head of $1.5-5 \mathrm{~m}$ with an air-steam mixture as the working fluid. The study proposed a mathematical model to simulate the internal processes associated with liquid piston engine. The mathematical model was then compared with a laboratory prototype and the parameters were mostly within $5-10 \%$ of the predicted models but compressor volume was recorded over $20 \%$ higher than that predicted.

Kurhe et al. [71] designed a heat engine using organic working fluid (acetone) to provide $20 \mathrm{~L} / \mathrm{h}$ of water per stroke and an operating head of $5 \mathrm{~m}$. The thermal water pump cycle functioned at a working temperature of $85^{\circ} \mathrm{C}$ to produce a system efficiency of $0.25-0.5 \%$. The engine used a chemical inert membrane that was displaced due to the pressure developed by the working fluid to pump water. The pressure of the working fluid was regulated using a heat exchanger where hot and cold water was pumped into the evaporate and condense the working fluid respectively. See Fig. 14. The efficiency of the system was low due the loss of heat through the membrane at the water interface. The need for work input necessitates the use of a separate power source.
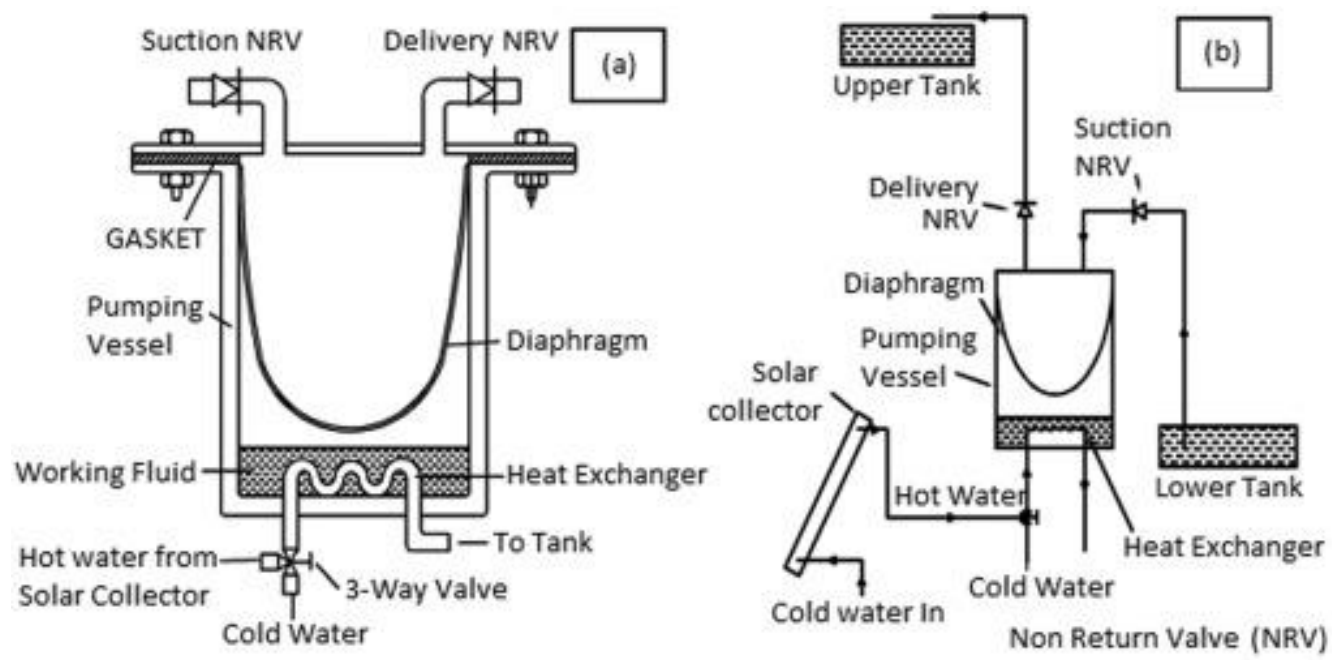

Fig. 14. (a) Pumping vessel assembly (b) Full system schematic [71].

Jokar and Tavakolpour-Saleh [72] introduced a novel active low temperature differential pump that is powered predominantly by solar thermal energy and operates on the basis of the Stirling cycle. The proposed system works with a liquid piston to provide effective sealing while reducing friction generally associated with solid power pistons and the cylinder encasing the piston. A flat plate solar collector with a reflecting surface is the heat source while the heat sink is a water-cooled surface and air is the working fluid in the main chamber that houses a displacer. A DC motor powered by a small battery and PV system controls the motion of the displacer piston to allow for adjustment of the working frequency to account for the pressure variation of the working fluid. For more controlled system, pressurised helium is recommended as a working fluid. The PV system also assists in initiating the displacer piston, as displayed in Fig. 15. 


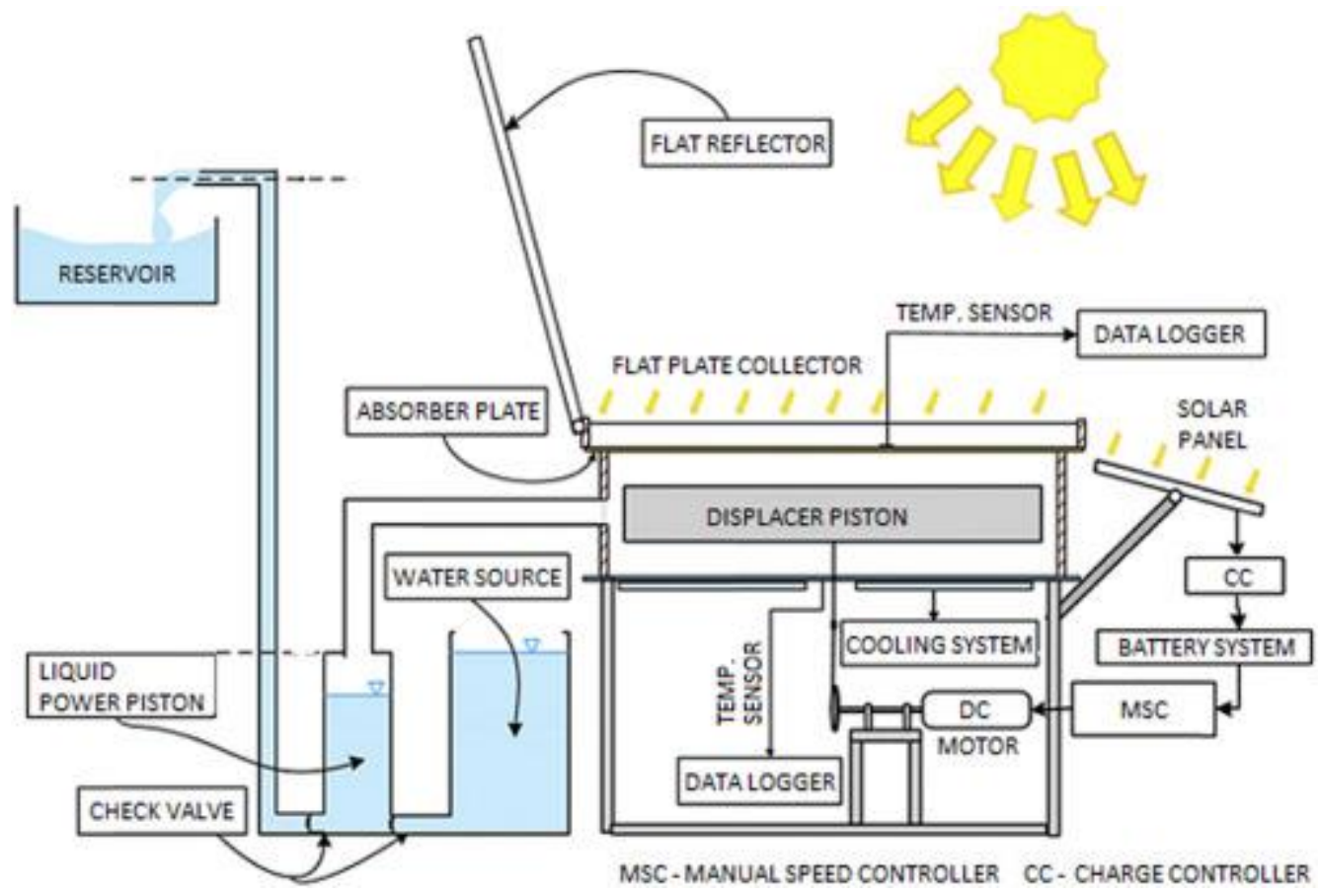

Fig. 15. Solar powered low temperature differential stirling pump [72].

A mathematical model was prepared and compared with small scale experimental results with the model results closely matching the experimental data. This is a novel idea of assisting the displacer piston, however, using the PV module and battery makes it very expensive.

Date and Akbarzadeh [73] conducted a theoretical study of a water pumping system powered by a solar pond and implementing a novel thermodynamic power cycle. The study proposed the system as an alternative to electrical pumps used in salt farms, that works at a temperature difference of $60{ }^{\circ} \mathrm{C}$ and acetone as the working fluid. The study introduced a two-stroke thermal powered pump cycle that extracts the work at the same time the working fluid is evaporated at a constant temperature while during the condensation the water that is being pumped adds the work on the working fluid.

The study proposes a hybrid system where the pump is thermally powered and all the auxiliary power for sensors, valves and the working fluid pump comes from a battery and PV system. The condenser and heat exchangers are contained within the solar pond system, as shown in Fig. 16. The analysis proposes that at $10 \%$ heat extraction of the annual average global solar radiation, a head of $22 \mathrm{~m}$ can be anticipated for operation up to 338 days of the year pumping $0.53 \mathrm{~m}^{3}$ of water per $\mathrm{m}^{2}$ of solar pond area per day. The research goes on to establish that with a floor area of $5200 \mathrm{~m}^{2}$ of solar pond $2800 \mathrm{~m}^{3} /$ day of salt water could be pumped from depths between 2-10 m. For this, a $20 \mathrm{~L}$ stroke volume will be required in conjunction with $0.01 \mathrm{~m}^{2}$ heat exchanger and $0.1 \mathrm{~m}^{2}$ condenser. 


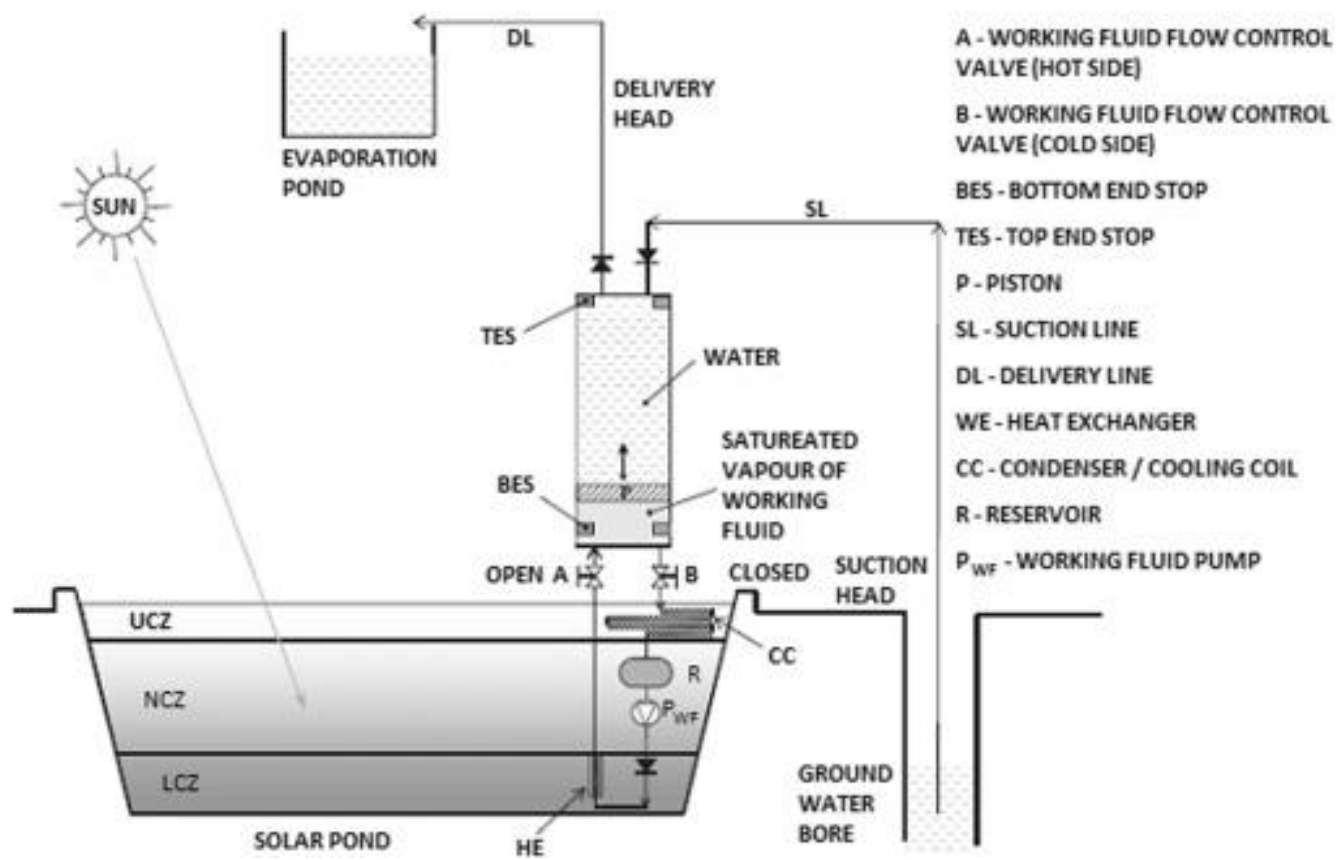

Fig. 16. Solar pond in conjunction with a two-stroke thermal water pump [73].

The thermal pump proposed can theoretically replace electrical pumps, however, the costs and practicality associated with the technology required experimentation work and further study.

Sitranon et al. [69] conducted a parametric study of the suction head assembly of a thermal water pump with steam as the working fluid and discussed its applications. The study analysed the amount of air that is required to be added to the steam working fluid and looked to shorten the cooling time by employing direct contact cooling. A 2-stroke liquid piston powered by an electrical heater was used to provide consistent heat source to the heating tank to transfer water from a well to a storage tank, as shown in Fig. 17. The study suggests that using air in conjunction with steam as the working fluid will lower the working temperature and thus make it more suitable for solar thermal use. Tests were conducted in Thailand and the results matched that of the simulation model used. At a temperature difference of about $60^{\circ} \mathrm{C}, 123.9 \mathrm{~L}$ of water was pumped requiring $19.73 \mathrm{MJ}$ of energy to provide a mean suction head of $6 \mathrm{~m}$ and a discharge head of $1 \mathrm{~m}$.

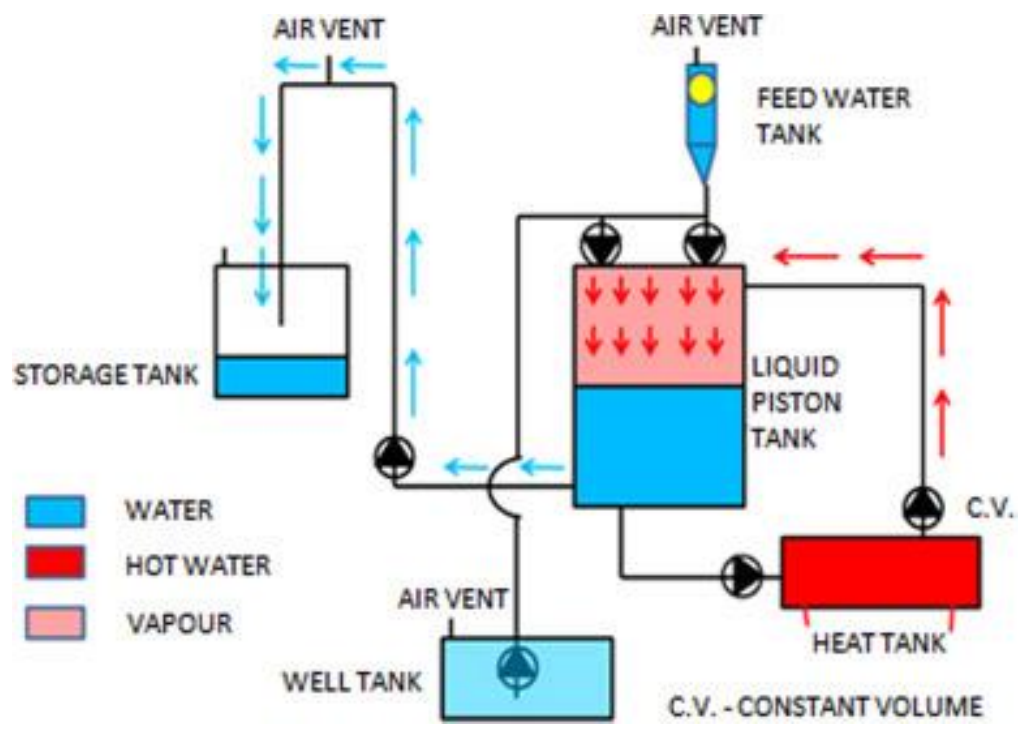

Fig. 17. 2-stroke liquid piston pump [69]. 


\section{Results and discussion}

In the current state, PV systems are far more viable in comparison to solar thermal systems especially as small-scale farming solutions in the technological sense. Assisted further by the drop of cost of solar cells, seamless integration with available technology, reduction in price of Lithium Ion batteries and rapid commercialisation of the technology. In this section, a summary of the advantages and disadvantages of the systems are presented in the context of small scale irrigation in the remote and rural areas of Sub-Saharan African region.

\subsection{PV technology}

The data from the reviews have been compiled and presented as per tabularised in Table 5. The Table focuses on the irrigation requirement of the system (including flowrate and pumping head), The PV module and power of the system utilised to meet the requirement, the area of the farm land and the cost of the technology.

The cost of PV technology is often compared to diesel powered systems. There is a clear advantage of PV systems over diesel powered systems in terms of the life time cost analysis, however, the initial investment for PV systems is much higher than diesel powered systems especially with regards to operational and maintenance costs. In comparison to other renewable energy systems such as wind and solar thermal systems reviewed, the investment cost is lower. Even then, a well-designed solar PV system can have a payback period of under 6 years, which so far is unmatched by other types of irrigation solutions in remote rural areas.

In terms of efficiency, the most efficient PV panels include the multi-Junction five-junction cells with $38.8 \pm 1.2 \%$ efficiency. However, the environmental impact of these cells is very high. Cadmium telluride $(\mathrm{CdTe})$ cells with conversion efficiency of $21.0 \pm 0.4 \%$ and a module efficiency of $19.1 \%$, has the least impact on the environment. CdTe cells produce the least amount of greenhouse gas emissions and have quickest payback period in comparison to all other solar PV technologies $[8,11]$.

DC motors are the preferred choice of motors for solar power systems less than $5 \mathrm{~kW}$ capacity. The maximum requirement for solar power to irrigate 1 ha land is less than $1 \mathrm{~kW}$ as per estimates by $\mathrm{R}$. López-Luque et al. [25] Hence for a small scale rural operation DC motors will be the better fit when compared to AC motors. DC motors with permanent magnet provide the highest torque, fastest response and the highest efficiency among DC motor systems. Permanent magnet DC motor in conjunction with diaphragm pump or positive displacement pumps show the highest pumping system efficiencies of $70 \%$, with positive displacement pumps doing better for higher heads and diaphragm pumps performing better for lower heads.

There are conflicting studies with regards to cost of PV system with and without the incorporation of battery systems. Some studies suggest that a simple overhead water tank may be enough while others argue that incorporating a battery system will reduce the size of solar panels required and provide the possibility of on demand energy use. O. Deveci et al. [22] for instance designed a $132 \mathrm{Wh} /$ day system in Turkey with just two PV panels $10 \mathrm{~W}$ each to power a battery which was enough to power a pumping system to irrigate 1 ha of land daily for $2 \mathrm{~h}$ for US\$582, while an equivalent non-battery powered system would cost 2.75 times more. Similar research in Thailand by K. Treephak et al. [45] however, disagrees sighting the cost of DC motor system without battery to be the most cost effective system for the irrigation of 1.6 acres of land having a payback period of 7 years (estimated cost US\$ 2000/ha) as compared to 9.3 (estimated cost US $\$ 2200$ ha) years for an equivalent system using battery. AC motor systems on the other hand were more expensive having a payback period of over 10 years with or without battery. Research by D. H. Muhsen et al. [7] has also shown that using aluminium foil as a reflective surface can be set-up to boost the irradiation during cloudy weather or when there is less irradiation. 
Table 5

Review summary of Solar PV water pumping.

\begin{tabular}{|c|c|c|c|c|c|c|c|c|c|}
\hline Author & Location & Function & Flowrate & Head & PV panels & $\begin{array}{l}\text { Power out } \\
\text { avg }\end{array}$ & Battery & Farm size & Cost \\
\hline Deveci [22] & Turkey & Trees & $610 \mathrm{l} / \mathrm{h}$ & $1 \mathrm{~m}$ & $2 \times 10 \mathrm{Wp}$ & $132 \mathrm{Wh}$ & Yes & - & $\$ 582$ \\
\hline Campana [43] & $\begin{array}{l}\text { Mongolia } \\
\text { China }\end{array}$ & $\begin{array}{l}2 \mathrm{~h} \text { irrigation } \\
\text { Alfaalfa }\end{array}$ & $50 \mathrm{~m}^{3} / \mathrm{ha}$ & $40 \mathrm{~m}(\mathrm{TDH})$ & - & $2.9 \mathrm{kWp}$ & - & - & $\begin{array}{l}\text { Investment } \\
\min -\$ 0.8 / \mathrm{Wp} \\
\max -\$ 2.0 / \mathrm{Wp}\end{array}$ \\
\hline Campana [24] & $\begin{array}{l}\text { Mongolia } \\
\text { China }\end{array}$ & Alfaalfa & $3.9 \mathrm{~m}^{3} / \mathrm{h}$ & $5 \mathrm{~m}$ & $6 \times 0.96 \mathrm{kWp}$ & - & - & - & $\$ 2 / W_{p}$ \\
\hline López-Luque [25] & $\begin{array}{l}\text { Almeira } \\
\text { Spain }\end{array}$ & Olive Trees & $2 \mathrm{~m}^{3} / \mathrm{h}$ & $\begin{array}{l}40 \mathrm{~m} \\
60 \mathrm{~m} \\
80 \mathrm{~m}\end{array}$ & - & $\begin{array}{l}150 \mathrm{~W} / \mathrm{ha} \\
250 \mathrm{~W} / \mathrm{ha} \\
300 \mathrm{~W} / \mathrm{ha}\end{array}$ & - & $\begin{array}{l}250 \text { trees } \\
\text { /ha }\end{array}$ & $\$ 2.14 / \mathrm{Wp}$ \\
\hline \multirow[t]{5}{*}{ Chandel [10] } & - & Orchard & $3.4-3.8 \mathrm{l} / \mathrm{h}$ & - & - & $900 \mathrm{Wp}$ & - & - & - \\
\hline & $\begin{array}{l}\text { Madina } \\
\text { Saudi Arabia }\end{array}$ & - & $22 \mathrm{~m}^{3} /$ day & - & $\begin{array}{l}24 \text { Modules } \\
8 \text { series } 3 \text { parallel }\end{array}$ & - & - & - & - \\
\hline & $\begin{array}{l}\text { Gunung-kidul } \\
\text { India }\end{array}$ & water Supply & $0.4-0.9 \mathrm{l} / \mathrm{s}$ & $1400 \mathrm{~m}$ & 32 PV Panels & $3200 \mathrm{Wp}$ & - & - & - \\
\hline & Spain & Orchard & $161 \mathrm{~m}^{3} /$ day & - & - & $6 \mathrm{kWp}$ & - & 10 ha & - \\
\hline & Algeria & - & $60 \mathrm{~m}^{3} /$ day & $14.5 \mathrm{~m}$ & - & - & - & - & $\$ 0.04 / \mathrm{m}^{3}$ \\
\hline Chandel $[30,74]$ & $\begin{array}{l}\text { Himachal } \\
\text { Pradesh } \\
\text { India }\end{array}$ & Test & $\begin{array}{l}5500 \mathrm{l} / \mathrm{h} \\
4929 \mathrm{l} / \mathrm{d}^{\mathrm{a}}\end{array}$ & - & $\begin{array}{l}12 \text { mono- } \mathrm{C}-\mathrm{Si} \\
\text { PV modules }\end{array}$ & $\begin{array}{l}396 \mathrm{Wp} \\
235 \mathrm{Wp}^{\mathrm{a}}\end{array}$ & Yes & - & - \\
\hline Kumar [27] & $\begin{array}{l}\text { Hyderabad } \\
\text { India }\end{array}$ & - & $9001 / h$ & $4.5 \mathrm{~m}$ & $1.44 \mathrm{~m}^{2}$ & $148 \mathrm{~W}$ & Yes & 2 ha & $\begin{array}{l}\$ 410 \\
\text { (full system) }\end{array}$ \\
\hline Hossain [26] & $\begin{array}{l}\text { Dhaka } \\
\text { Bangladesh }\end{array}$ & $\begin{array}{l}\text { Brinjal } \\
\text { Tomato } \\
\text { Wheat } \\
\text { Rice }\end{array}$ & $100 \mathrm{l} / \mathrm{min}$ & $33.5 \mathrm{~m}$ & $\begin{array}{l}1050 \text { Panels } \\
\text { with tracking }\end{array}$ & $1440 \mathrm{~W}$ & Yes & $\begin{array}{l}520 \mathrm{~m}^{2} \\
520 \mathrm{~m}^{2} \\
496 \mathrm{~m}^{2} \\
220 \mathrm{~m}^{2}\end{array}$ & $\$ 5660$ \\
\hline Bengh-anem [75] & Saudi Arabia & Test & - & $50-80 \mathrm{~m}$ & $\begin{array}{l}\text { PV array of } 24 \text { mono } \\
\text { crystalline solar cells }(8 \mathrm{~S} \times \\
\text { 3P) }\end{array}$ & $1800 \mathrm{Wp}$ & No & - & - \\
\hline \multirow[t]{4}{*}{ Treephak [45] } & Thailand & Rice & $15 \mathrm{~m}^{3} / \mathrm{h}$ & $3.9 \mathrm{~m}$ & $250 \mathrm{~W} \times 6-\mathrm{AC}$ & $1500 \mathrm{~W}$ & No & $0.5 \mathrm{ha}$ & $\$ 2800$ \\
\hline & & & & & $250 \mathrm{~W} \times 4-\mathrm{DC}$ & $1000 \mathrm{~W}$ & No & 0.5 ha & $\$ 2000$ \\
\hline & & & & & $295 \mathrm{~W} \times 4-\mathrm{AC}$ & $1180 \mathrm{~W}$ & Yes & $0.5 \mathrm{ha}$ & $\$ 2800$ \\
\hline & & & & & $295 \mathrm{~W} \times 3-\mathrm{DC}$ & $885 \mathrm{~W}$ & Yes & $0.5 \mathrm{ha}$ & $\$ 2200$ \\
\hline Yahyaoui [31] & Brazil & Tomato & $200 \mathrm{~m}^{3} / \mathrm{h}$ & - & - & $10-10,000 \mathrm{~W}$ & Yes & $10 \mathrm{ha}$ & - \\
\hline Reca [29] & $\begin{array}{l}\text { Almeira } \\
\text { Spain }\end{array}$ & Tomato & $60,000 \mathrm{l} / \mathrm{h}$ & $40 \mathrm{~m}$ & - & $600 \mathrm{~W} / \mathrm{ha}$ & No & 1.9 ha & $\$ 2.14$ / \\
\hline Jones [34] & Jordan & Desalination & $\begin{array}{l}4000- \\
15,000 \mathrm{~m}^{3} / \mathrm{ha} / \\
\mathrm{yr}\end{array}$ & $25-100 \mathrm{~m}$ & - & $245 \mathrm{~W}$ & Yes & $4-10$ ha & $\begin{array}{l}\$ 1.25-\varsigma \\
/ \mathrm{W}\end{array}$ \\
\hline \multirow{5}{*}{ Sontake [9] } & Nigeria & - & $20 \mathrm{~m}^{3} /$ day & - & $60 \mathrm{WP} \times 28$ & - & Yes & - & - \\
\hline & Germany & Portable water & - & $5-125 \mathrm{~m}$ & $90 \mathrm{nos}$ & $180 \mathrm{kWp}$ & - & - & - \\
\hline & $\begin{array}{l}\text { Bushland } \\
\text { Texas }\end{array}$ & - & $2-81 / \min$ & $3-70 \mathrm{~m}$ & - & $160 \mathrm{~W}$ & - & - & - \\
\hline & - & - & $10-165 \mathrm{l} / \mathrm{h}$ & $10-16 \mathrm{~m}$ & $2 \times 45 \mathrm{~W}$ & - & - & - & - \\
\hline & - & - & $40 \mathrm{~m}^{3} /$ day & $10 \mathrm{~m}$ & - & $300-500 \mathrm{Wp}$ & - & - & - \\
\hline $\begin{array}{l}\text { Setiawan et al. } \\
\text { [23] }\end{array}$ & Indone-sia & Portable Water & $0.2-0.9 \mathrm{l} / \mathrm{s}$ & $218 \mathrm{~m}$ & $32 \times 100 \mathrm{Wp}$ & $3200 \mathrm{Wp}$ & no & - & - \\
\hline \multirow[t]{16}{*}{ Muhsen [7] } & Saudi Arabia & - & $600 \mathrm{l} / \mathrm{h}$ & $50 \mathrm{~m}$ & - & $0.98 \mathrm{kWp}$ & - & - & - \\
\hline & Egypt & - & $150 \mathrm{~m}^{3} /$ day & 30 & - & $6.048 \mathrm{kWp}$ & - & - & - \\
\hline & Algeria & - & $6 \mathrm{~m}^{3} /$ day & - & $\begin{array}{l}(4 \mathrm{~S} \times 3 \mathrm{P}),(3 \mathrm{~S} \times 4 \mathrm{P}) \\
\text { BP Saturn }\end{array}$ & - & - & - & - \\
\hline & $\begin{array}{l}\text { Kairouan } \\
\text { Tunisia }\end{array}$ & - & $6.5-30 \mathrm{~m}^{3} /$ day & $65-112 \mathrm{~m}$ & - & $2.1 \mathrm{kWp}$ & - & - & - \\
\hline & $\begin{array}{l}\text { Ghardaia } \\
\text { Algeria }\end{array}$ & - & $4-6 \mathrm{~m}^{3} /$ day & $19-35 \mathrm{~m}$ & - & - & - & - & - \\
\hline & $\begin{array}{l}\text { Madina } \\
\text { Saudi Arabia }\end{array}$ & - & $<22 \mathrm{~m}^{3} /$ day & $80 \mathrm{~m}$ & $\begin{array}{l}(6 \mathrm{~S} \times 3 \mathrm{P}),(12 \mathrm{~S} \times 2 \mathrm{P}),(8 \mathrm{~S} \times \\
3 \mathrm{P}), \\
(6 \mathrm{~S} \times 4 \mathrm{P}) \times 75 \mathrm{Wp}\end{array}$ & - & - & - & - \\
\hline & $\begin{array}{l}\text { Oran } \\
\text { Algeria }\end{array}$ & - & $6-65 \mathrm{l} / \mathrm{m}$ & $0.6-11 \mathrm{~m}$ & - & $1.5 \mathrm{kWp}$ & - & - & - \\
\hline & $\begin{array}{l}\text { Tall Hassan } \\
\text { Jordan }\end{array}$ & - & $45 \mathrm{~m}^{3} /$ day & $105 \mathrm{~m}$ & - & $5.9 \mathrm{kWp}$ & - & - & - \\
\hline & Greece & - & $20 \mathrm{~m}^{3} /$ day & $30 \mathrm{~m}$ & $(2 \mathrm{~S} \times 6 \mathrm{P}) \times 51 \mathrm{Wp}$ & - & - & - & - \\
\hline & Turkey & - & $\begin{array}{l}18 \mathrm{~m}^{3} / \text { day } \\
52 \mathrm{~m}^{3} / \text { day }\end{array}$ & $20 \mathrm{~m}$ & $\begin{array}{l}2 \times 230 \mathrm{Wp} \\
8 \times 200 \mathrm{Wp}\end{array}$ & - & - & - & - \\
\hline & $\begin{array}{l}\text { New Delhi } \\
\text { India }\end{array}$ & - & $38 \mathrm{~m}^{3} /$ day & $5 \mathrm{~m}$ & $4 \mathrm{~S} \times 5 \mathrm{P}$ & - & - & - & - \\
\hline & $\begin{array}{l}\text { Purwodad } \\
\text { Indonesia }\end{array}$ & - & $\begin{array}{l}1.44-3.24 \mathrm{~m}^{3} / \\
\mathrm{h}\end{array}$ & $218.34 \mathrm{~m}$ & $8 \mathrm{~S} \times 4 \mathrm{P}$ & $3.2 \mathrm{kWp}$ & - & - & - \\
\hline & $\begin{array}{l}\text { Louata } \\
\text { Tunisia }\end{array}$ & - & $\begin{array}{l}7.7-14.7 \mathrm{~m}^{3} / \\
\text { day }\end{array}$ & $65 \mathrm{~m}$ & $14 \mathrm{~S} \times 3 \mathrm{P}$ & $2.1 \mathrm{kWp}$ & - & - & - \\
\hline & $\begin{array}{l}\text { Madina } \\
\text { Saudi Arabia }\end{array}$ & - & $\leq 33 \mathrm{~m}^{3} /$ day & $50-80 \mathrm{~m}$ & $8 \mathrm{~S} \times 3 \mathrm{P}$ & $1.8 \mathrm{kWp}$ & - & - & - \\
\hline & Bejaia & - & $43.66-$ & $11 \mathrm{~m}$ & $6 \mathrm{~S} \times 3 \mathrm{P}$ & $990 \mathrm{Wp}$ & - & - & - \\
\hline & $\begin{array}{l}\text { Algeria } \\
\text { Nigeria }\end{array}$ & - & $\begin{array}{l}27.91 \mathrm{l} / \mathrm{min} \\
10-30 \mathrm{~m}^{3} / \text { day }\end{array}$ & $40 \mathrm{~m}$ & - & $840-2520 \mathrm{Wp}$ & - & - & - \\
\hline Tiwari and & India & Domestic Use & $20,232 \mathrm{~L} / \mathrm{d}$ & & $3 \mathrm{~S} \times 2 \mathrm{P}$ & 850 & No & - & - \\
\hline Kalamkar [76] & & & $23,317 \mathrm{~L} / \mathrm{d}$ & & $4 \mathrm{~S} \times 2 \mathrm{P}$ & 1000 & & & \\
\hline & & & $24,374 \mathrm{~L} / \mathrm{d}$ & & $5 \mathrm{~S} \times 2 \mathrm{P}$ & 1020 & & & \\
\hline Kabalci [77] & Turkey & Vineyard & $\begin{array}{l}22,130 \mathrm{~L} / \mathrm{d} \\
400 \mathrm{~m}^{3} / \mathrm{d}\end{array}$ & $100 \mathrm{~m}$ & $\begin{array}{l}7 \mathrm{~S} \\
245 \mathrm{Wp} \text { Panels connected } \\
((2 \mathrm{P}) \times \mathrm{S}) \times 2\end{array}$ & $\begin{array}{l}1040 \\
2000 \mathrm{Wp}\end{array}$ & Yes & - & - \\
\hline Sarkar [46] & Bangladesh & Farm land ${ }^{\mathrm{b}}$ & $\begin{array}{l}128 \mathrm{~m}^{3} / \mathrm{d} \\
373 \mathrm{~m}^{3} / \mathrm{d} \\
740 \mathrm{~m}^{3} / \mathrm{d} \\
645 \mathrm{~m}^{3} / \mathrm{d} \\
300 \mathrm{~m}^{3} / \mathrm{d}\end{array}$ & $\begin{array}{l}12.8 \mathrm{~m} \\
9.71 \mathrm{~m} \\
16 \mathrm{~m} \\
14.6 \mathrm{~m} \\
35 \mathrm{~m}\end{array}$ & Poly-crystalline $\mathrm{Si}$ & $\begin{array}{l}3.5 \mathrm{~kW} \\
4 \mathrm{~kW} \\
7.5 \mathrm{~kW} \\
11 \mathrm{~kW} \\
7.5 \mathrm{~kW}\end{array}$ & Yes & - & $\$ 1800 / \mathrm{kW}$ \\
\hline
\end{tabular}


Several other studies quote varying values of power output and costs, hence, the conclusion from these studies is that the best way to optimise the cost and design of the PV powered system is to understand the requirements of the crop and perform extensive site survey to analyse the working conditions of the system. The more data available the more efficient the design of the system and thus lower the costs. It is often due to the lack of data that PV systems costs increase as more complex and intelligent systems are integrated into the system. One of the major reasons for the use of the battery is the functionality of the pump. Inconsistent irradiation and thus power output from the PV panels may vary restricting the time of operation of the pumps.

Based on the literature reviews, and considering the case for drip irrigation, the simplest, most cost effective solar PV system is one consisting of cadmium telluride PV module at $19.5 \%$ efficiency. The panel combines with a permanent magnet DC motor driven pumps (positive displacement pump for higher heads or diaphragm pump for lower heads) capable of providing 70\% pump system efficiency. Using a storage tank instead of battery, this system provides an overall theoretical system efficiency of $13.65 \%$, as shown in Fig. 18. The system will function when solar radiation is available and water from the storage tank can be used for drip irrigational purposes.

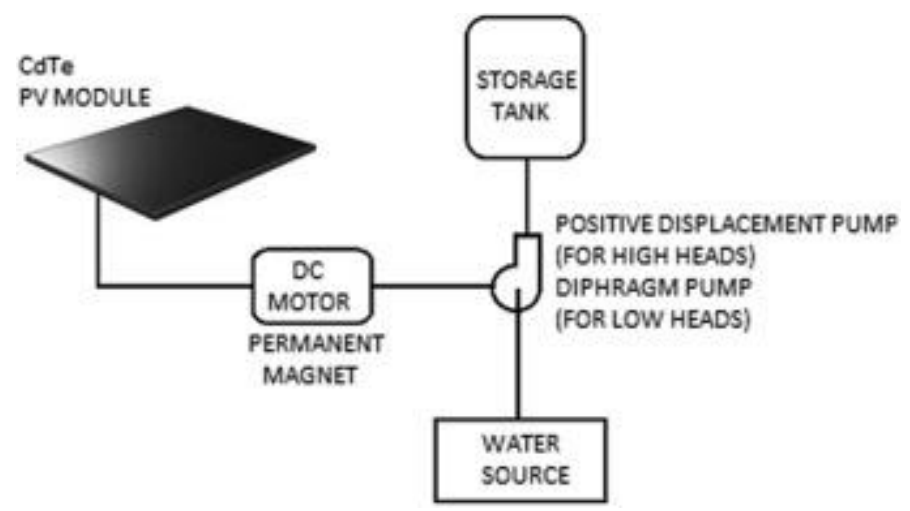

Fig. 18. Schematic of the most effective Solar PV water pumping system for remote rural areas based on literature reviews.

That brings us to the drawbacks of the PV technology, one of the major issues with Solar PV technologies is the degradation of power of PV cells due to long term exposure. Generally, the degradation is measured to be $0.8 \%$ per year as per climatic conditions in India [30], however, elevated temperatures and humidity in Sub-Saharan Africa may pose further challenge to PV technology. The issue here is that, it is a parameter that has not been extensively studied, hence in pursuit to compensate for the loss of degradation more intelligent systems (such as ANN, MPPT and Fuzzy Logic based controllers) may have to be incorporated and that will drive the cost up. Furthermore, any maintenance or modifications of the system will be expensive if resources such as replacement cells are not readily available in the region in case of shipping or operational misuse.

Implementing PV technology is costly enough for Farmers. Weak knowledge-exchange and lack of incentives further creates further difficulty for innovative practices [78].

While PV technology is 10 times less harmful to the environment than coal it is still 4 times more harmful than Nuclear and wind turbine power plants [8,50]. Furthermore, the carbon footprint of transportation is also required to be considered for the Sub-Saharan African region as PV panels are not produced in this region.

Accumulation of dust on the Panels, overheating during energy conversion and functioning at higher temperatures are some of the other main issues associated with the reduction of performance of solar panels. 


\subsection{Solar thermal technologies}

The data from the reviews of solar thermal technologies have been compiled and presented as per tabularised in Table 6. The data focuses on the irrigation attributes of the system including flowrate and pumping head, the thermal system and power output of the system utilised for irrigation and the cost of the technology. The reviews and data reveal a lack of real life testing to solar thermal technologies hence farm size data is not available for solar thermal technologies for comparison with PV technologies.

Table 6

Review summary of solar thermal water pumping technology.

\begin{tabular}{|c|c|c|c|c|c|c|c|c|}
\hline Author & Location & Flowrate & Head & Power cycle & Collector type & $\begin{array}{l}\text { Temp difference } \\
\left({ }^{\circ} \mathrm{C}\right)\end{array}$ & $\begin{array}{l}\text { Power out } \\
\text { avg }\end{array}$ & Cost \\
\hline Mahkamov [62] & UK & - & - & Stirling & - & $70-35$ & $20-40 \mathrm{~W}$ & - \\
\hline \multirow{21}{*}{$\begin{array}{l}\text { Delgado- Torrez } \\
\quad[57]\end{array}$} & Paris & $2.2 \mathrm{~m}^{3} / \mathrm{h}$ & - & Rankine & Conical & - & - & - \\
\hline & France & & & & Reflector & & & \\
\hline & Paris & $71 / \min$ & $3 \mathrm{~m}$ & Rankine & Parabolic & - & - & - \\
\hline & $\begin{array}{l}\text { Pasadena } \\
\text { US }\end{array}$ & $5.3 \mathrm{~m}^{3} / \mathrm{min}$ & $3.6 \mathrm{~m}$ & Rankine & $\begin{array}{l}\text { Truncated cone } \\
10 \mathrm{~m} \text { dia top } \\
4.5 \mathrm{~m} \text { dia bottom }\end{array}$ & - & 7.35 & - \\
\hline & - & - & - & Rankine & Flat Plate & - & $14.7 \mathrm{~kW}$ & - \\
\hline & $\begin{array}{l}\text { Pensilvania } \\
\text { US }\end{array}$ & - & - & Rankine & $\begin{array}{l}\text { Solar Pond } \\
11,200 \mathrm{~m}^{2}\end{array}$ & - & 2.57 & - \\
\hline & $\begin{array}{l}\text { Pensilvania } \\
\text { US }\end{array}$ & $11.3-12 \mathrm{~m}^{3} / \mathrm{min}$ & $10 \mathrm{~m}$ & Rankine & $\begin{array}{l}\text { Wooden Boxes } \\
1000 \mathrm{~m}^{2}\end{array}$ & - & $\begin{array}{l}10.29- \\
11.76 \mathrm{~kW}\end{array}$ & - \\
\hline & $\begin{array}{l}\text { Meadi } \\
\text { Egypt }\end{array}$ & $27 \mathrm{~m}^{3} / \mathrm{min}$ & - & Rankine & $\begin{array}{l}\text { Parabolic Trough } \\
60 \mathrm{~m} \times 4 \mathrm{~m}\end{array}$ & - & $40.42 \mathrm{~kW}$ & - \\
\hline & $\begin{array}{l}\text { Mali } \\
\text { Africa }\end{array}$ & $11.3 \mathrm{~m}^{3} /$ day & $45.7 \mathrm{~m}$ & Rankine & - & - & - & - \\
\hline & - & - & $4.8 \mathrm{~m}$ & Ericsson & Parabolic & - & - & - \\
\hline & $\begin{array}{l}\text { Arizona } \\
\text { US }\end{array}$ & $38 \mathrm{~m}^{3} / \mathrm{min}$ & - & Rankine & $\begin{array}{l}\text { Parabolic } \\
554 \mathrm{~m}^{2}\end{array}$ & - & - & - \\
\hline & $\begin{array}{l}\text { New Mexico } \\
\text { US }\end{array}$ & $2.6 \mathrm{~m}^{3} / \mathrm{min}$ & $34 \mathrm{~m}$ & Rankine & $\begin{array}{l}\text { Parabolic } \\
622.4 \mathrm{~m}^{2}\end{array}$ & - & - & - \\
\hline & $\begin{array}{l}\text { Guanajuato } \\
\text { Mexico }\end{array}$ & $1000 \mathrm{~m}^{3} /$ day & - & Rankine & $\begin{array}{l}\text { Flat Plate } \\
2499 \mathrm{~m}^{2}\end{array}$ & - & - & - \\
\hline & $\begin{array}{l}\text { Dakar } \\
\text { Senegal }\end{array}$ & $8-10 \mathrm{l} / \mathrm{min}$ & $13-14 \mathrm{~m}$ & Rankine & $\begin{array}{l}\text { Flat Plate } \\
6 \mathrm{~m}^{2}\end{array}$ & - & - & - \\
\hline & $\begin{array}{l}\text { San Luis } \\
\text { Mexico }\end{array}$ & $2.5 \mathrm{~m}^{3} /$ day & - & - & - & - & $25 \mathrm{~kW}$ & - \\
\hline & Various & $30 \mathrm{~m}^{3} /$ day & 20 & - & $\begin{array}{l}\text { Flat Plate } \\
100 \mathrm{~m}^{2}\end{array}$ & - & - & - \\
\hline & Mexico & - & - & Rankine & Parabolic Trough & - & $1 \mathrm{~kW}$ & - \\
\hline & $\begin{array}{l}\text { Arizona } \\
\text { US }\end{array}$ & - & - & Rankine & $\begin{array}{l}\text { Parabolic Trough } \\
2140 \mathrm{~m}^{2}\end{array}$ & - & - & - \\
\hline & Egypt & - & - & Rankine & $\begin{array}{l}\text { Flat Plate } \\
384 \mathrm{~m}^{2}\end{array}$ & - & $10 \mathrm{~kW}$ & - \\
\hline & - & $14.61 \mathrm{l} / \mathrm{min}$ & $3 \mathrm{~m}$ & Rankine & $\begin{array}{l}4 \times \text { Flat Plate } \\
1 \mathrm{~m}^{2} \text { each }\end{array}$ & - & - & - \\
\hline & India & $6.5 \mathrm{~m}^{3} /$ day & $11.2 \mathrm{~m}$ & Rankine & $\begin{array}{l}\text { Flat Plate } \\
7 \mathrm{~m}^{2}\end{array}$ & - & - & - \\
\hline \multirow[t]{5}{*}{$\begin{array}{l}\text { Delgado- Torrez } \\
\quad \text { [57] }\end{array}$} & India & - & - & Rankine & $\begin{array}{l}6 \times \text { Parabolic } \\
9 \mathrm{~m} \mathrm{dia}\end{array}$ & - & $\begin{array}{l}20 \mathrm{~kW} \\
\left(500{ }^{\circ} \mathrm{C} \text { Steam }\right)\end{array}$ & - \\
\hline & Iran & $20 \mathrm{~m}^{3} /$ day & - & Rankine & Flat Plate & - & - & - \\
\hline & India & $2 \mathrm{~m}^{3} /$ day & $6 \mathrm{~m}$ & $\begin{array}{l}\text { Organic } \\
\text { Rankine }\end{array}$ & Parabolic & - & - & - \\
\hline & UK & $0.5-2 \mathrm{~m}^{3} / \mathrm{h}$ & - & $\begin{array}{l}\text { Liquid } \\
\text { Piston }\end{array}$ & - & MAX Temp: 95 & $0.8-3 \mathrm{~kW}$ & - \\
\hline & $\begin{array}{l}\text { Kolkata } \\
\text { India }\end{array}$ & 240 l/day & $15 \mathrm{~m}$ & $\begin{array}{l}\text { Metal } \\
\text { Hydride }\end{array}$ & $\begin{array}{l}\text { Flat Plate } \\
1 \mathrm{~m}^{2}\end{array}$ & $22-62$ & - & - \\
\hline Lakew [63] & - & - & - & Rankine & - & $\begin{array}{l}80 \\
\text { (plus } 60^{\circ} \mathrm{C} \text { Low } \\
\text { level heat source }\end{array}$ & $2800-3750 \mathrm{~kW}$ & - \\
\hline \multirow[t]{2}{*}{ Tchanche [64] } & UK & - & - & $\begin{array}{l}\text { Organic } \\
\text { Rankine }\end{array}$ & - & 55 & $1.47 \mathrm{~kW}$ & $\$ 30,000$ \\
\hline & $\begin{array}{l}\text { Sendai } \\
\text { Japan }\end{array}$ & $0.016 \mathrm{~kg} / \mathrm{s}$ & - & - & & - & $350 \mathrm{~W}$ & - \\
\hline Date [73] & Australia & $140 \mathrm{~m}^{3} /$ day & $35 \mathrm{~m}$ & $\begin{array}{l}\text { 2-Stroke } \\
\text { Liquid Piston }\end{array}$ & $\begin{array}{l}\text { Solar Pond } \\
5200 \mathrm{~m}^{2}\end{array}$ & - & - & - \\
\hline Kurhe [71] & India & $20 \mathrm{~L} / \mathrm{h}$ & $5 \mathrm{~m}$ & $\begin{array}{l}\text { 2-Stroke Diaphragm } \\
\text { pump }\end{array}$ & $\begin{array}{l}\text { Flat plate } \\
\text { Collector }\end{array}$ & $50-60$ & - & - \\
\hline Baral [66] & $\begin{array}{l}\text { Busan } \\
\text { South Korea }\end{array}$ & - & - & $\begin{array}{l}\text { Organic } \\
\text { Rankine }\end{array}$ & Evacuated Tubes & $65-95$ & $\begin{array}{l}0.4 \mathrm{~kW}- \\
1.38 \mathrm{~kW}\end{array}$ & $\$ 25,800$ \\
\hline Jokar [72] & Iran & $0.125 \mathrm{l} / \mathrm{s}$ & $1.5 \mathrm{~m}$ & Stirling & $\begin{array}{l}\text { Flat Plate } \\
\text { Reflector } 2 \times 1 \mathrm{~m}\end{array}$ & 100 & $1-2 \mathrm{~W}$ & - \\
\hline Baral [67] & Nepal & $\begin{array}{l}2190-11100 \mathrm{~m}^{3} / \\
\text { year }\end{array}$ & $150 \mathrm{~m}$ & $\begin{array}{l}\text { Organic } \\
\text { Rankine }\end{array}$ & $\begin{array}{l}\text { Evacuated Tubes } \\
150-200 \mathrm{~m}^{2}\end{array}$ & $60-100$ & $1-5 \mathrm{~kW}$ & $\begin{array}{l}\$ 13,000 \\
(1 \mathrm{~kW}) \\
\$ 66,900 \\
(5 \mathrm{~kW})\end{array}$ \\
\hline Sitranon [69] & Thailand & $60-95 \mathrm{l} / \mathrm{h}$ & $2-6 \mathrm{~m}$ & $\begin{array}{l}\text { Liquid } \\
\text { Piston }\end{array}$ & - & 70 & - & - \\
\hline Moonsri [68] & Thailand & $192.2-218.8 \mathrm{l} /$ day & $1-5 \mathrm{~m}$ & $\begin{array}{l}\text { Liquid } \\
\text { Piston }\end{array}$ & Flat Plate & $42.9-46.7$ & - & - \\
\hline Bataineh [70] & Jordan & - & - & Rankine & $\begin{array}{l}\text { Parabolic Trough } \\
526 \mathrm{~m}^{2}\end{array}$ & - & $30 \mathrm{~kW}$ & $\$ 0.075 / \mathrm{kWh}$ \\
\hline
\end{tabular}


Solar thermal powered water pumping technologies can be categorised into two types, conventional pumps and unconventional. Conventional Technologies generally utilise the Rankine Cycle whereas unconventional systems make us of the vapour cycle, metal hydride systems or liquid pistons. Conventional systems are shown to produce more power in comparison to unconventional systems however, conventional systems are generally very large and complex. Because of this and the low efficiency the conventional systems do not pose to be an effective solution. Unconventional technologies on the other hand generally pose lower pumping potential or in the case of Metal hydride solutions, pose high costs.

The most compact type of solar concentrators are dish concentrators which in conjunction with a double axis tracking mechanism can provide up to $1200{ }^{\circ} \mathrm{C}$ which is also on the high cost side. At low costs the options include the flat plate / reflector collectors capable to provide up to $100{ }^{\circ} \mathrm{C}$ temperatures. In the median Liner Fresnal collectors provide both a low cost and high temperature potential of up to $400{ }^{\circ} \mathrm{C}$. The most frequently used collector technology however is the Parabolic trough collectors shown in the studies capable of providing temperatures up to $500{ }^{\circ} \mathrm{C}$ with a single axis tracking mechanism [64].

The organic Rankine cycle systems are the most common form of concentrated solar thermal power generation system utilised for irrigation. These systems are generally multi facet as they would be highly inefficient for the sole purpose for irrigation. Most systems with this technology undertakes irrigation in conjunction with either desalination or rural power generation. Small systems are shown to generate between $1.5 \mathrm{~kW}$ power with a payback period of 20 years, while larger systems are capable of a maximum $40 \mathrm{~kW}$ to provide a pumping capacity of $27 \mathrm{~m}^{3} / \mathrm{min}$. These systems may be favourable for investment by a group of farmers in a village. However, as a standalone system it is very large and immobile in comparison to PV panels while the investment costs are similar.

Stirling cycle systems are also used for irrigational purposes. These systems generate lower power; however, they are compact and are easy to manufacture. The Stirling cycle based technology systems are investigated mostly to reduce the cost, thus the research undertaken investigated medium to low power solar collection / temperatures with a difference of $60-95^{\circ} \mathrm{C}$. Higher temperatures should be able to provide better outputs. The systems investigated in this paper provide relatively low head losses and flows; however, provisions are shown to add more heat into the system or inject mechanical assistance to further elevate the technology to provide a bigger output. The main advantage with the Stirling cycle system is that any heat source may be used to provide the thermal energy and hence may be suitable for use in a hybrid system. Liquid piston systems pump water directly which is then collected in a storage tank to irrigate fields using the drip irrigation method.

Two stroke piston systems have also been proposed that function like the Stirling cycle systems. Metal hydride systems have shown the best results in this providing the largest pumping head and flow of up to 20001 using just a $1 \mathrm{~m}^{2}$ flat plate collector. However, the use of metal hydrides makes this technology inaccessible to remote locations and farmers.

Based on the research undertaken solar thermal technologies utilising the Stirling engine holds the highest potential for small scale remote farms usage if the correct infrastructure is available for solar power concentration. Solar concentration technology that is cheap, effective and portable is required for this. Parabolic concentrators and dish concentrators provide compact solutions; however, they can be expensive to purchase. Local alternatives utilising local materials to build concentration systems may be proposed, which will reduce the cost as well as carbon footprint of the system. Utilising the technology to produce electricity is not viable, hence direct mechanical use for pumping is recommended in conjunction with a water storage tank is the optimal solution, this can be seen in Fig. 19. 


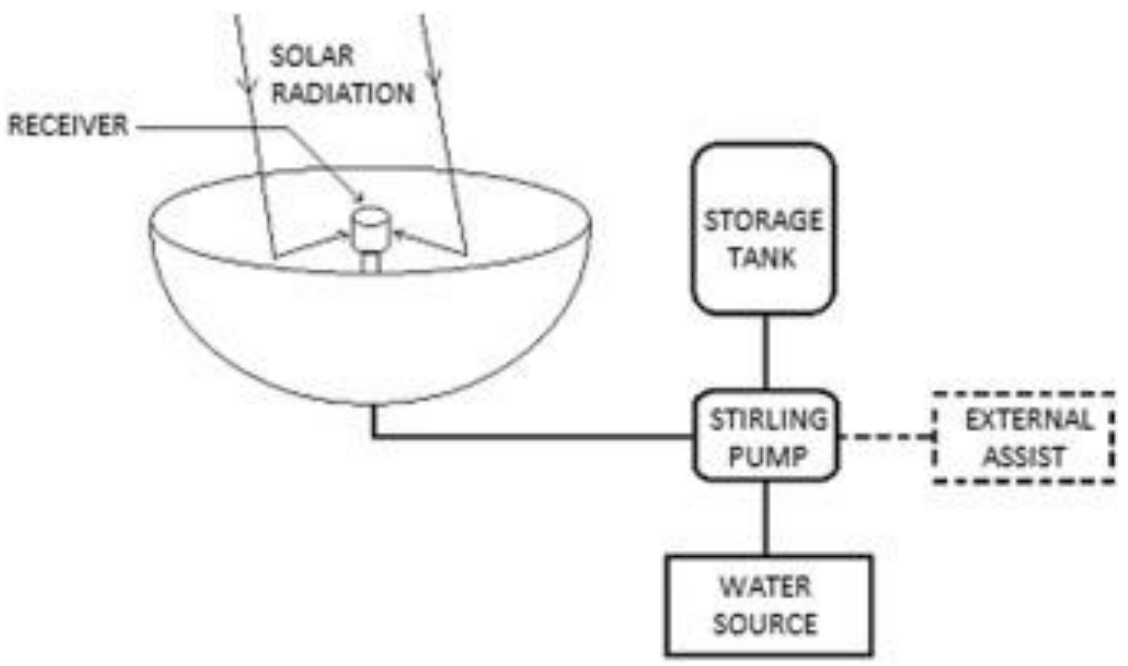

Fig. 19. Schematic of the most effective solar thermal water pumping system for remote rural areas based on literature reviews.

A hybrid system may be proposed that combines the Stirling pump with and external mechanical system assist for the displacer in the case of inadequate solar irradiation like that proposed by Jokar and Tavakolpour-Saleh [72]; however, their use of solar panel and battery system defeats the investment cost aspect. Other external assistance solutions such as wind power may be investigated based on local resources availability.

\section{Future of solar powered water pumping systems}

In terms of efficiency, solar thermal pumping systems conjure a maximum measured efficiency of $3 \%$ in comparison to $6 \%$ from photovoltaics. But the efficiency shouldn't be the main priority in the selection of the appropriate technology, especially since the source is renewable. The main factors hence are Cost and the impact on the environment.

A locally produced solar thermal system would be more cost effective and environmentally friendly in comparison to PV panels, as far as initial investments are concerned for remote area irrigation. The issue with regards to solar thermal powered technologies is that, the amount of research undertaken on these irrigation systems is very low; however, commercial technology exists that utilise thermal energy, but have not been studied critically.

The ease and accessibility of Stirling systems make it a viable option for testing and innovation, take for instance, SUNORBIT, a company from Germany, have produced a concentrated solar system capable of $500 \mathrm{~W}, 10 \mathrm{~m}$ head, 80,000 L/day known as the SUNPULSE [79]. See Fig. 20. The system uses a foldable dish concentrator with a heat storage powering a $\gamma$-type Stirling engine. The pump has been tested across Europe, Africa, Asia and Australia and is estimated to cost US\$2500. 

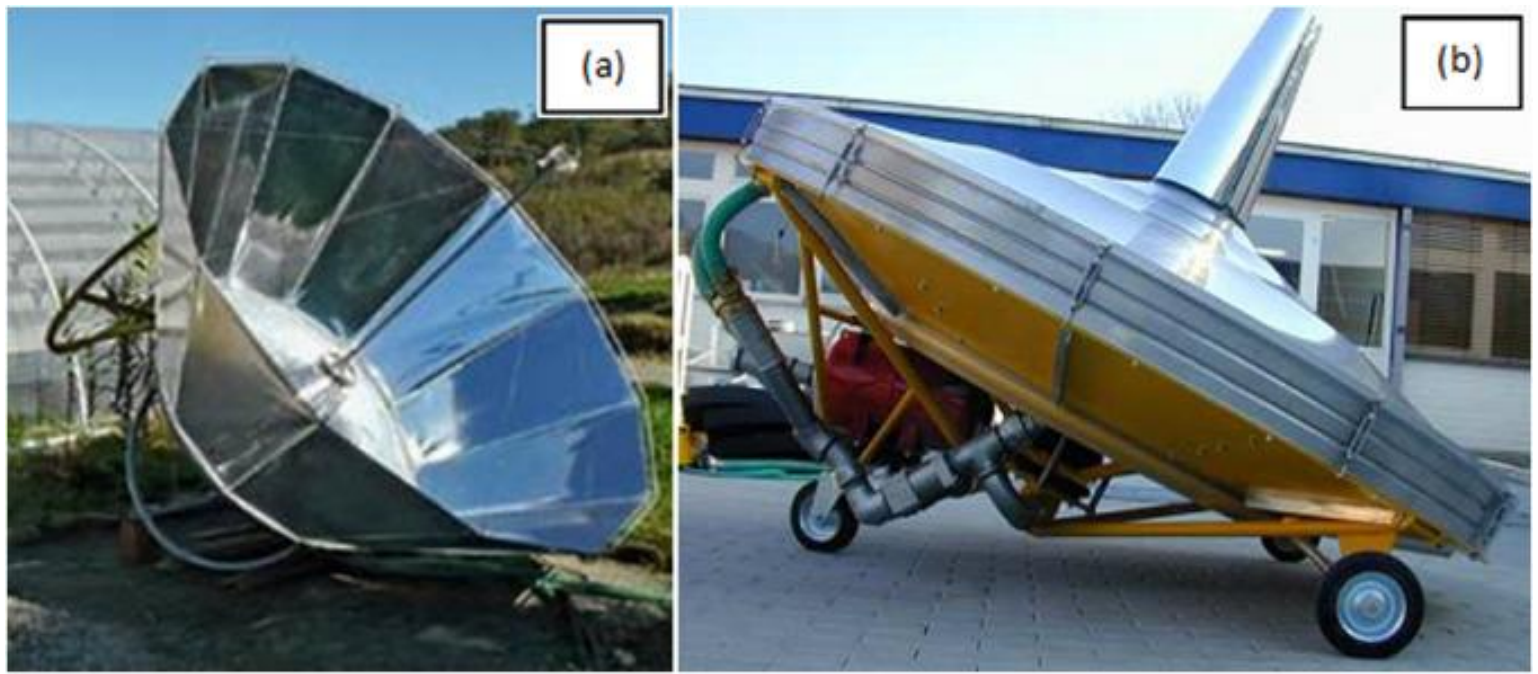

Fig. 20. (a) Solar Stirling water pump with dish [80] (b) SUNPULSE Stirling system [81].

Tested by TÜV labs, the system is shown to meet the World Bank target of water cost for rural areas of 6 cents $/ \mathrm{m}^{3}$. As per tests, the system designed can provide 2.4 cents $/ \mathrm{m}^{3}$.

Similar systems have been researched recently however, most of the research conducted focus on the potential of the Stirling cycle for the generation of electricity. These systems tend to be more expensive including dual axis solar tracking and large concentrators. Barreto and Canhoto [82] modelled a Stirling engine including a dish solar concentrator system, thermal receiver, and functioned as per three cycles, thermal cycle, mechanical ( $\beta$-type Stirling engine) and electric energy conversion. The global efficiency of the system was recorded to be $10.4 \%$. Combine that a $70 \%$ efficient pumping system, a pumping system efficiency of $7.28 \%$ available.

Based on the concentration factor, the efficiency was mapped as per shown in Fig. 21. There is a definite loss by converting mechanical energy to electrical energy in this system. Furthermore, a $\beta$-type Stirling engine is not the most efficient Stirling engine.

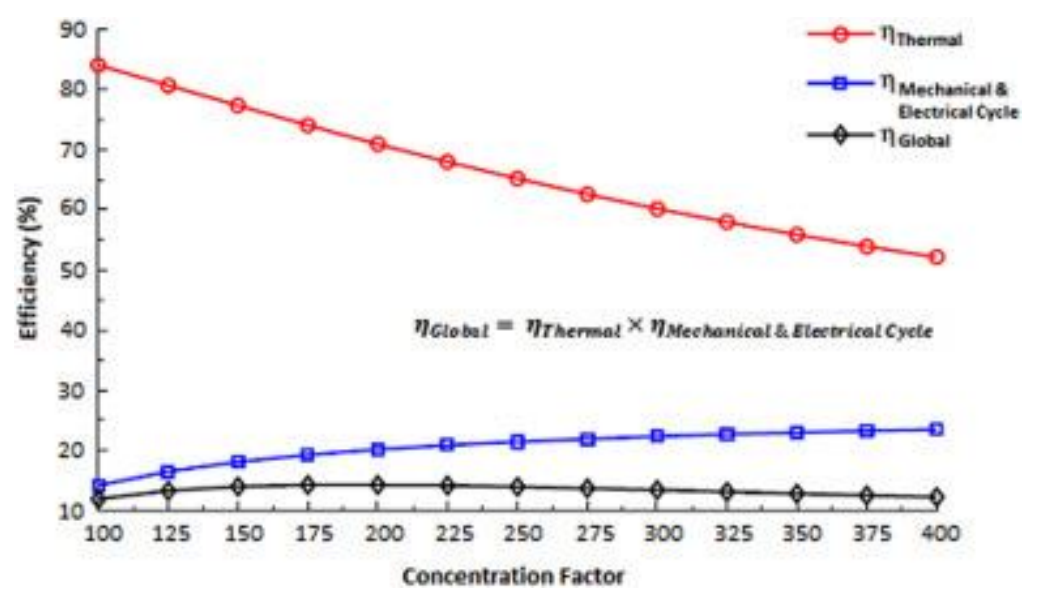

Fig. 21. Solar concentration factor and its effect on efficiency [82].

Using the basis of the study performed by Barreto and Canhoto [82], and understanding the SUNPULSE technology will help develop a model based on theoretical and real life results to help design systems that best matches the scenarios presented for remote rural irrigation and thus develop apposite solar thermal water pumping technology to match the performance of solar PV solutions, while keeping overall costs down and being more environmental friendly. 


\section{Conclusions}

PV powered water pumping technologies are well developed, easily accessible and require almost no maintenance over the course of the lifetime of the technology. Studies suggest that the best way to optimise the cost and design of the PV powered system is to understand the requirements of the crop and perform extensive site survey to analyse the working conditions of the system. This is seen in relation to the use of a battery system where cost savings have been achieved in certain scenarios without using the battery while in other applications it was found that a battery in fact reduces costs. While the cost of PV system, over the course of its lifetime, is much lower in comparison to diesel powered systems, the initial investment cost is much higher and often too much to bare for small scale rural farmers. Furthermore, if the purpose of solar panels is to reduce the impact on the environment, it falls short due to a substantial carbon footprint because of the manufacturing and transportation impacts of the technology.

This study identifies that there is a huge potential for solar thermal technology to meet the requirements of the small scale rural farmer by using a solar thermal water pumping system but the research on these systems are minimal, there is very few data available on the feasibility of these technologies especially for small scale purposes. Organic Rankine Cycle systems are the most common form of concentrated solar thermal power generation systems utilised for irrigation, however, these systems are feasible only on a large scale. That said, commercial technologies and studies in recent development in Stirling engines positively depict solar thermal water pumping capabilities keeping costs to a minimum and appreciably reducing the carbon footprint through the utilisation of local resources and local manufacture while matching the performance of PV technology.

\section{Acknowledgement}

The Authors are grateful to the Grantham Centre for Sustainable Futures working in conjunction with the University of Sheffield (Charity number: X1089) for their support in sponsoring the PhD research program.

\section{References}

[1] Kashaigili JJ. Ground water Availability and Use in Sub-Saharan Africa. Srilanka: International Water Management Institute; 2012. http://dx.doi.org/10.5337/ 2012.213.

[2] Pavelic P, Villholth KG, Shu Y, Rebelo L-M, Smakhtin V. Smallholder groundwater irrigation in Sub-Saharan Africa: country-level estimates of development potential. Water Int 2013;38:392-407. http://dx.doi.org/10.1080/02508060.2013.819601.

[3] International Renewable Energy Agency (IRENA). Africa 2030: Roadmap for a renewable energy future. REmap 2030 Program:72; 2015. 〈http://dx.doi.org/10. 1017/CBO9781107415324.004〉.

[4] FAO. Farm size|FAO|Food and Agriculture Organization of the United Nations; 2012. 〈http://www.fao.org/family-farming/data-sources/dataportrait/farm-size/ en/〉.

[5] Cavero J, Faci JM, Martínez-Cob A. Relevance of sprinkler irrigation time of the day on alfalfa forage production. Agric Water Manag 2016;178:304-13. http:// dx.doi.org/10.1016/j.agwat.2016.10.008.

[6] Ramos JS, Ramos HM. Solar powered pumps to supply water for rural or isolated zones: a case study. Energy Sustain Dev 2009;13:151-8. http://dx.doi.org/ 10.1016/j.esd.2009.06.006. 
[7] Muhsen DH, Khatib T, Nagi F. A review of photovoltaic water pumping system designing methods, control strategies and field performance. Renew Sustain Energy Rev 2017;68:70-86. http://dx.doi.org/10.1016/j.rser.2016.09.129.

[8] Gopal C, Mohanraj M, Chandramohan P, Chandrasekar P. Renewable energy source water pumping systems - a literature review. Renew Sustain Energy Rev 2013;25:351-70. http://dx.doi.org/10.1016/j.rser.2013.04.012.

[9] Sontake VC, Kalamkar VR. Solar photovoltaic water pumping system - a comprehensive review. Renew Sustain Energy Rev 2016;59:1038-67. http:// dx.doi.org/10.1016/j.rser.2016.01.021.

[10] Chandel SS, Nagaraju Naik M, Chandel R. Review of solar photovoltaic water pumping system technology for irrigation and community drinking water supplies. Renew Sustain Energy Rev 2015;49:1084-99. http://dx.doi.org/10.1016/ j.rser.2015.04.083.

[11] Green M, Emery K, Hishikawa Y, Warta W, Dunlop ED, Levi DH, et al. Solar cell efficiency tables (version 49) Martin. Prog Photovolt Res Appl 2017;25:3-13. http://dx.doi.org/10.1002/pip.1160.

[12] North Arizona Wind and sun. What is maximum power point tracking (MPPT) n.d. 〈https://www.solar-electric.com/mppt-solar-charge-controllers.html//.

[13] Jordan DC, Kurtz SR. Photovoltaic degradation rates - an analytical review. Prog Photovolt Res Appl 2013:21. http://dx.doi.org/10.1002/pip.1182.

[14] Yahya HN, Sambo AS. Design and installation of solar photovoltaic powered water pumping system at Usmanu Danfodiyo University, Sokoto. 6; 1995. p. 311-2.

[15] Hamidat A, Benyoucef B, Hartani T. Small-scale irrigation with photovoltaic water pumping system in Sahara regions. Renew Energy 2003;28:1081-96. http:// dx.doi.org/10.1016/S09601481(02)00058-7.

[16] Ali A, Hamza AZT. Performance of submersible PV solar pumping systems under conditions in the Sudan. Sol Electr Photovolt Wind 1995;6:491-5. http:// dx.doi.org/10.1016/0960-1481(95)00049$\mathrm{P}$.

[17] Bucher W. Aspects of solar water pumping in remote regions. Energy Sustain Dev 1996;3:8-27. http://dx.doi.org/10.1016/S0973-0826(08)60201-X.

[18] Vick BD, Clark RN. Determining the optimum solar water pumping system for domestic use. Livest Watering Irrigation 1992.

[19] Merino GG, Lagos LO, Gontupil JE. Monitoring and evaluation of a direct coupled photovoltaic pumping system. Appl Eng Agric 2008;24:277-84. http://dx.doi.org/ 10.13031/2013.24495.

[20] Taufik OiA, Anwari M, Taufik M Modeling and simulation of photovoltaic water pumping system. In: Proceedings of - 2009 3rd Asia international conference model simulation, AMS 2009; 2009. p. 497-502. 〈http://dx.doi.org/10.1109/AMS. 2009.85〉.

[21] Mahmoud M, Mahmoud MM, Kukhun WR, Daud A. Efficiency improvement of a dual PV water pumping system on a desert well by solar matched load control. Int J Energy Eng 2013;3:151-7.

[22] Deveci O, Onkol M, Unver HO, Ozturk Z. Design and development of a low-cost solar powered drip irrigation system using Systems Modeling Language. J Clean Prod 2015;102:529-44. http://dx.doi.org/10.1016/j.jclepro.2015.04.124. 
[23] Setiawan AA, Purwanto DH, Pamuji DS, Huda N. Development of a solar water pumping system in karsts rural area tepus, gunungkidul through student community services. Energy Procedia 2014;47:7-14. http://dx.doi.org/10.1016/j.egypro.2014.01.190.

[24] Campana PE, Li H, Zhang J, Zhang R, Liu J, Yan J. Economic optimization ofphotovoltaic water pumping systems for irrigation. Energy Convers Manag 2015;95:32-41. http://dx.doi.org/10.1016/j.enconman.2015.01.066.

[25] López-Luque R, Reca J, Martínez J. Optimal design of a standalone direct pumping photovoltaic system for deficit irrigation of olive orchards. Appl Energy 2015;149:13-23. http://dx.doi.org/10.1016/j.apenergy.2015.03.107.

[26] Hossain MA, Hassan MS, Mottalib MA, Ahmmed S. Technical and economic feasibility of solar pump irrigations for eco-friendly environment. Procedia Eng 2015;105:670-8. http://dx.doi.org/10.1016/j.proeng.2015.05.047.

[27] Kumar M, Reddy KS, Adake RV, Rao CVKN. Solar powered micro-irrigation system for small holders of dryland agriculture in India. Agric Water Manag 2015;158:112-9. http://dx.doi.org/10.1016/j.agwat.2015.05.006.

[28] Srivastava RC, Bhatnagar PR. Gravity-fed Drip Irrigation System for Hilly Terraces of the Northwest Himalayas, 21. Springer-Verlag; 2002. p. 151-7. http:// dx.doi.org/10.1007/s00271-0020058-y.

[29] Reca J, Torrente C, López-Luque R, Martínez J. Feasibility analysis of a standalone direct pumping photovoltaic system for irrigation in Mediterranean greenhouses. Renew Energy 2016;85:1143-54. http://dx.doi.org/10.1016/j.renene.2015.07.056.

[30] Chandel SS, Nagaraju Naik M, Sharma V, Chandel R. Degradation analysis of 28 year field exposed mono-c-Si photovoltaic modules of a direct coupled solar water pumping system in western Himalayan region of India. Renew Energy 2015;78:193-202. http://dx.doi.org/10.1016/j.renene.2015.01.015.

[31] Yahyaoui I, Tadeo F, Vieira M. Energy and water management for drip-irrigation of tomatoes in a semi- arid district. Agric Water Manag 2016. http://dx.doi.org/ 10.1016/j.agwat.2016.08.003.

[32] Sami M, Shiekhdavoodi MJ, Pazhohanniya M, Pazhohanniya F. Environmental comprehensive assessment of agricultural systems at the farm level using fuzzy logic: a case study in cane farms in Iran. Environ Model Softw 2014;58:95-108. http://dx.doi.org/10.1016/j.envsoft.2014.02.014.

[33] Rawat R, Kaushik SC, Lamba R. A review on modeling, design methodology and size optimization of photovoltaic based water pumping, standalone and grid connected system. Renew Sustain Energy Rev 2016;57:1506-19. http:// dx.doi.org/10.1016/j.rser.2015.12.228.

[34] Jones MA, Odeh I, Haddad M, Mohammad AH, Quinn JC. Economic analysis of photovoltaic (PV) powered water pumping and desalination without energy storage for agriculture. Desalination 2016;387:35-45. http://dx.doi.org/10.1016/j.desal.2016.02.035.

[35] Vick BD, Clark RN. Experimental investigation of solar powered diaphragm and helical pumps. Sol Energy 2011;85:945-54. http://dx.doi.org/10.1016/j.solener.2011.02.011.

[36] Mohammedi A, Mezzai N, Rekioua D, Rekioua T. Impact of shadow on the performances of a domestic photovoltaic pumping system incorporating an MPPT control: a case study in Bejaia, North Algeria. Energy Convers Manag 2014;84:20-9. http://dx.doi.org/10.1016/j.enconman.2014.04.008. 
[37] Posorski R. Photovoltaic water pumps, an attractive tool for rural drinking water supply. Sol Energy 1996;58:155-63. http://dx.doi.org/10.1016/S0038-092X(96) 00060-6.

[38] Campana PE, Leduc S, Kim M, Olsson A, Zhang J, Liu J, et al. Suitable and optimal locations for implementing photovoltaic water pumping systems for grassland irrigation in China. Appl Energy 2015;185:1879-89. http://dx.doi.org/10.1016/ j.apenergy.2016.01.004.

[39] Zhang C, Elia Campana P, Yang J, Yan J. Economic performance of photovoltaic water pumping systems with business model innovation in China. Energy Convers Manag 2016. http://dx.doi.org/10.1016/j.enconman.2016.10.069.

[40] Elkholy MM, Fathy A. Optimization of a PV fed water pumping system without storage based on teaching-learning-based optimization algorithm and artificial neural network. Sol Energy 2016;139:199-212. http://dx.doi.org/10.1016/j.solener.2016.09.022.

[41] Pawar PJ, Rao RV. Parameter optimization of machining processes using teachinglearning-based optimization algorithm. Int J Adv Manuf Technol 2013;1. http:// dx.doi.org/10.1007/s00170-013-49616.

[42] Closas A, Rap E. Solar-based groundwater pumping for irrigation: sustainability, policies, and limitations. Energy Policy 2017;104:33-7. http://dx.doi.org/ 10.1016/j.enpol.2017.01.035.

[43] Campana PE, Li H, Yan J. Techno-economic feasibility of the irrigation system for the grassland and farmland conservation in China: photovoltaic vs. wind power water pumping. Energy Convers Manag 2015;103:311-20. http://dx.doi.org/ 10.1016/j.enconman.2015.06.034.

[44] Allen RG, Rick G. Food and Agriculture Organization of the United Nations. Crop Evapotranspiration: Guidelines for Computing Crop Water Requirements. Food and Agriculture Organization of the United Nations; 1998.

[45] Treephak K, Thongpron J, Somsak D, Saelao J, Patcharaprakiti N. An economic evaluation comparison of solar water pumping system with engine pumping system for rice cultivation. Jpn J Appl Phys 2015;54:08KH01.

[46] Sarkar MNI, Ghosh HR. Techno-economic analysis and challenges of solar powered pumps dissemination in Bangladesh. Sustain Energy Technol Assess 2017;20:33-46. http://dx.doi.org/10.1016/j.seta.2017.02.013.

[47] Meah K, Fletcher S, Ula S. Solar photovoltaic water pumping for remote locations. Renew Sustain Energy Rev 2008;12:472-87. http://dx.doi.org/10.1016/ j.rser.2006.10.008.

[48] De Wild-Scholten MJ. Energy payback time and carbon footprint of commercial photovoltaic systems. Sol Energy Mater Sol Cells 2013;119:296-305. http:// dx.doi.org/10.1016/j.solmat.2013.08.037.

[49] Sinha P. Life cycle materials and water management for CdTe photovoltaics. Sol Energy Mater Sol Cells 2013;119:271-5. http://dx.doi.org/10.1016/j.solmat.2013.08.022.

[50] Laleman R, Albrecht J, Dewulf J. Life cycle analysis to estimate the environmental impact of residential photovoltaic systems in regions with a low solar irradiation. Renew Sustain Energy Rev 2011;15:267-71. http://dx.doi.org/10.1016/ j.rser.2010.09.025.

[51] Parikh MM, Bhattacharya AK. Wind data analysis for studying the feasibility of using windmills for irrigation. Energy Agric 1984;3:129-36. http://dx.doi.org/ 10.1016/0167-5826(84)90015-9.

[52] Das D, Ram Gopal M. Studies on a metal hydride based solar water pump. Int J Hydrog Energy 2004;29:103-12. http://dx.doi.org/10.1016/S0360-3199(03) 00044-2. 
[53] Ferreira AC, Nunes ML, Teixeira JC, Martins LB, Teixeira SFCF. Thermodynamic and economic optimization of a solar-powered stirling engine for micro- cogeneration purposes. In: Proceedings of Ecos 2015 - 28th international conference on efficiency, cost, optimization, simulation and environmental impact of energy systems 2015;111:13 pgs.

[54] Felix A Farret MGS. Appendix C the stirling engine; 2006. 〈http://dx.doi.org/10. 1002/0471755621〉.

[55] Bagheri A, Bostanci H, Foster PR. Preliminary analysis of an innovative rotary displacer stirling engine. ASME Int Mech Eng Congr Expo Proc 2015. http:// dx.doi.org/10.1115/IMECE2015-52455, [6A-2015].

[56] Ahmadi MH, Ahmadi M-A, Pourfayaz F. Thermal models for analysis of performance of Stirling engine: a review. Renew Sustain Energy Rev 2017;68:168-84. http://dx.doi.org/10.1016/j.rser.2016.09.033.

[57] Delgado-Torres AM. Solar thermal heat engines for water pumping: an update. Renew Sustain Energy Rev 2009;13:462-72. http://dx.doi.org/10.1016/ j.rser.2007.11.004.

[58] Pytilinski JT. Solar energy installations for pumping irrigation water. Sol Energy 1978;21:255-62. http://dx.doi.org/10.1016/0038-092X(78)90001-4.

[59] Wong Y, Sumathy K. Solar thermal water pumping systems: a review. Renew Sustain Energy Rev 1999;3:185-217. http://dx.doi.org/10.1016/S1364-0321(98) 00018-5.

[60] Spencer LC. A comprehensive review of small solar-powered heat engines: Part II. research since 1950-“conventional" engines up to $100 \mathrm{~kW}$. Sol Energy 1989;43:197-210. http://dx.doi.org/10.1016/0038-092X(89)90020-0.

[61] Wong YW, Sumathy K. Thermodynamic analysis and optimization of a solar thermal water pump. Appl Therm Eng 2001;21:613-27. http://dx.doi.org/ 10.1016/S1359-4311(00)00065-X.

[62] Mahkamov K, Orda EP. Solar thermal water pumps: a preliminary analysis of the working process. J Sol Energy Eng Trans ASME 2005;127:29-36. http:// dx.doi.org/10.1115/1.1767191.

[63] Lakew AA, Bolland O, Ladam Y. Theoretical thermodynamic analysis of Rankine power cycle with thermal driven pump. Appl Energy 2011;88:3005-11. http:// dx.doi.org/10.1016/j.apenergy.2011.03.029.

[64] Tchanche BF, Lambrinos G, Frangoudakis A, Papadakis G. Low-grade heat conversion into power using organic Rankine cycles - a review of various applications. Renew Sustain Energy Rev 2011;15:3963-79. http://dx.doi.org/ 10.1016/j.rser.2011.07.024.

[65] Nguyen VM, Doherty PS, Riffat SB. Development of a prototype low-temperature Rankine cycle electricity generation system. Appl Therm Eng 2001;21:169-81. http://dx.doi.org/10.1016/S13594311(00)00052-1.

[66] Baral S, Kim D, Yun E, Kim K. Experimental and thermoeconomic analysis of small-scale solar organic Rankine cycle (SORC) system. Entropy 2015;17:2039-61. http://dx.doi.org/10.3390/e17042039.

[67] Baral S, Kim KC. Stand-alone solar organic Rankine cycle water pumping system and its economic viability in Nepal. Sustain 2016;8:1-18. http://dx.doi.org/ 10.3390/su8010018.

[68] Moonsri P, Kunchornrat J, Namprakai P. Hybrid energy thermal water pump for producing hot water from a shallow well in Thailand. J Energy Eng 2015;4015023:4015023. http://dx.doi.org/10.1061/(ASCE)EY.1943- 7897.0000278. 
[69] Sitranon J, Lertsatitthanakorn C, Namprakai P, Prathinthong N, Suparos T, Roonprasang N. Performance enhancement of solar water heater with a thermal water pump. J Energy Eng 2015;141:4014036. http://dx.doi.org/10.1061/(ASCE) EY.1943-7897.0000216.

[70] Bataineh KM. Optimization analysis of solar thermal water pump. Renew Sustain Energy Rev 2016;55:603-13. http://dx.doi.org/10.1016/j.rser.2015.10.146.

[71] Kurhe N, Funde A, Gokhale P, Jadkar S, Ghaisas S, Date A. Development of low temperature heat engine for water pumping application. Energy Procedia 2017;110:292-7. http://dx.doi.org/10.1016/j.egypro.2017.03.142.

[72] Jokar H, Tavakolpour-Saleh AR. A novel solar-powered active low temperature differential Stirling pump. Renew Energy 2015;81:319-37. http://dx.doi.org/ 10.1016/j.renene.2015.03.041.

[73] Date A, Akbarzadeh A. Theoretical study of a new thermodynamic power cycle for thermal water pumping application and its prospects when coupled to a solar pond. Appl Therm Eng 2013;58:51121. http://dx.doi.org/10.1016/j.applthermaleng.2013.05.004.

[74] Chandel SS, Naik MN, Chandel R. Review of performance studies of direct coupled photovoltaic water pumping systems and case study. Renew Sustain Energy Rev 2017;76:163-75. http://dx.doi.org/10.1016/j.rser.2017.03.019.

[75] Benghanem M, Daffallah KO, Alamri SN, Joraid AA. Effect of pumping head on solar water pumping system. Energy Convers Manag 2014;77:334-9. http:// dx.doi.org/10.1016/j.enconman.2013.09.043.

[76] Tiwari AK, Kalamkar VR. Performance investigations of solar water pumping system using helical pump under the outdoor condition of Nagpur, India. Renew Energy 2016;97:737-45. http://dx.doi.org/10.1016/j.renene.2016.06.021.

[77] Kabalci Y, Kabalci E, Canbaz R, Calpbinici A. Design and implementation of a solar plant and irrigation system with remote monitoring and remote control infrastructures. Sol Energy 2016;139:50617. http://dx.doi.org/10.1016/j.solener.2016.10.026.

[78] Levidow L, Zaccaria D, Maia R, Vivas E, Todorovic M, Scardigno A. Improving water-efficient irrigation: prospects and difficulties of innovative practices. Agric Water Manag 2014;146:84-94. http://dx.doi.org/10.1016/j.agwat.2014.07.012.

[79] Sunvention sunpulse. Sunvention stirling machine.

[80] Coen Reith. Solar stirling engine water pump. JOVOTO; 2013. 〈https://uploads1. jovo.to/idea_attachments/579121/solar-stirling-common-waterpump-1_big.jpg? 1448775192). [Accessed 20 January 2017].

[81] Vineeth CS. Beginners Guide to Stirling Engines; 2011. 〈https://books.google.com. sg/books?id=zTdzKxQaqNcC\&pg=PT85\&source=gbs_selected_ pages $\& \mathrm{cad}=2 \# \mathrm{v}=$ onepage $\& \mathrm{q} \& \mathrm{f}=$ false $\rangle$.

[82] Barreto G, Canhoto P. Modelling of a Stirling engine with parabolic dish for thermal to electric conversion of solar energy. Energy Convers Manag 2017;132:119-35. http://dx.doi.org/10.1016/j.enconman.2016.11.011. 